\title{
Yusufeli Barajı Antropojenik Etkilerinin Peyzaj Planlama Açısından Değerlendirilmesi
}

\author{
Belgin Yılmam ${ }^{1}$, Hilal Turgut ${ }^{2, *}$ (1) \\ ${ }^{1}$ Artvin Çoruh Üniversitesi, Fen Bilimleri Enstitüsü, Peyzaj Mimarlığı Anabilim Dalı, 08000, Artvin. \\ ${ }^{2}$ Artvin Çoruh Üniversitesi, Sanat ve Tasarım Fakültesi, Peyzaj Mimarlığı Bölümü, 08000, Artvin.
}

\section{Özet}

Yirminci yüzyllın ikinci yarısından sonra önemli seviyelere ulașan insan kaynaklı doğa tahribatının uzun bir süre daha dünya gündemini meşgul edeceği görünüyor. Dünya nüfusundaki ve buna bağll olarak enerji ve besin gereksinimindeki artı̧̧ doğal kaynaklar üzerindeki baskllarl ve tahribatları da arttırmıştır. Bu baskı ve tahribatlar ekosistemlerin işleyişinde önemli aksaklıklara ve doğal dengede kimi zaman geriye dönülemez bozulmalara neden olmaktadır. Bu çalışmada, Yusufeli Barajı'nın yapım ve üretim süreçlerinde ortaya çıkan antropojenik baskıların belirlenmesi amaçlanmıştır. Kılıçkaya, Öğdem ve Yusufeli bölgeleri Yusufeli Barajı’ndan etkilendikleri için çalışma alanı olarak seçilmişlerdir. Antropojenik etkilerin belirlenmesinde uydu görüntüleri ve CBS yazılımları kullanılmıştır. Çalışma sonucunda elde edilen verilere göre, Yusufeli Barajı'nın su tutmaya başlamasıyla birlikte yaklaşı 33 km²'lik su yüzeyinin oluşacağı tespit edilmiştir. Yusufeli Barajı'nın tamamlanmasının ardından yaklaşık 612 ha orman ve 62 ha tarım arazisi yok olacaktır. Arazi kabiliyet sinıfları bakımından yapılan değerlendirmelerde, I. sinıf arazilerin \%100'ünün, II. sinıf arazilerin $\% 69$ 'unun, III. sinıf arazilerin \%81'inin, IV. sinıf arazilerin \%7'sinin, VI. sinif arazilerin \%1'inin ve VII. sinif arazilerin \%1'inin baraj rezervuar sahası içinde kalacağ̀ görülmüştür. Yusufeli Barajı'ndan en fazla etkilenen Yusufeli ilçe merkezinin taşınacağı yeni yerleşim alanı yaklaşık 640 ha'lık bir alana sahiptir ve üç bölgeden oluşacaktır. Bu alanların oluşturulması için önemli miktarda kazı-dolgu işlemi yapılmıștır. İmar planına göre yeni yerleșim merkezinde 1300 konut için 21.6 ha, aktif yeșil alanlar için 9.65 ha ve pasif yeșil alanlar için ise 5.1 ha alan planlanmıştır. Bu çalışma ile Yusufeli Barajı ile ortaya çıkan antropojenik etkilerin olumsuz sonuçlarının en aza indirgenmesi için planlama önerileri sunulmuştur.

\section{Anahtar Sözcükler}

Antropojenik Etkiler, Peyzaj Planlama, Artvin, Alan Kullanım Değişimleri

\section{Evaluation of the Anthropogenic Impacts of Yusufeli Dam in terms of Landscape Planning}

\begin{abstract}
It seems that the destruction of man-made nature, which reached important levels after the second half of the twentieth century, will occupy the world agenda for a long time. The increase in the world population and consequently the increasing need for energy and food have enhanced the pressures and damages on natural resources. These degradations lead to disruptions in the ecosystem functions and sometimes irreversible deterioration in natural balance. This study aims to determine the anthropogenic pressures in the construction and production processes of the Yusufeli Dam. Kllıçkaya, Ö̈̆dem, and Yusufeli regions were chosen as the study area because they were affected by the Yusufeli Dam. Satellite images and GIS software were used to determine the anthropogenic effects. As a result of the study, it was determined that the water surface of approximately $33 \mathrm{~km} 2$ will be formed with the water retention of Yusufeli Dam. After the completion of the Yusufeli Dam, 612ha forest and 62ha agricultural fields will be destroyed. In the assessment of land capability, it was determined that $100 \%$ of class I, 69\% of class II, $81 \%$ of class III, 7\% of class IV, $1 \%$ of class VI, and $1 \%$ of class VII will remain within the dam reservoir area. The new settlement area where Yusufeli district will move has an area of 640 ha and consists of three parts. A significant amount of excavation and filling operations have been carried out to create these areas. According to the zoning plan in the new settlement, 21.6 ha for 1300 residences, 9.65 ha for active green areas, and 5.1 ha for passive green areas were planned. In this study, planning suggestions are also presented to minimize the negative consequences of anthropogenic effects caused by Yusufeli Dam.
\end{abstract}

$\underline{\text { Keywords }}$

Anthropogenic Effects, Landscape Planning, Artvin, Land Use Change 


\section{Giriş}

Dünyanın oluşumundan bu yana nüfusun her geçen yıl giderek artması, iş ve istihdam sorunları ile barınma ihtiyacı gibi genel sorunların birikimi, doğal çevrenin üzerindeki baskıları arttırmıştır. İnsan ihtiyaçları, artan nüfus etkisi ile orantılı olarak büyümektedir. Bu da son elli yıl içerisinde doğa tahribatının oldukça hızlı bir şekilde ortaya çıkmasına sebep olmuştur. Türk Dil Kurumu'nun tanımına göre; doğada insanların yapmış olduğu etkiler antropojenik etkiler olarak tanımlanmıştır. Madencilik, endüstriyel etkiler, ulaşım, tarımsal faaliyetler, su yönetimi, savaşlar, iklim değişimleri vb. pek çok konularda yapılan çalışmalar ile antropojenik etkiler incelenmiştir (Walker 1991; Goudie 2007; Şerifaki 2006; Yetilmezsoy 2006; Gülgün vd. 2011; Gülgün vd. 2012; Ertek 2017; Özşahin ve Eroğlu 2017; Bağc1 ve Bahadır 2018; Küçük vd. 2018).

İnsanoğlunun ihtiyaçları arttıkça çevresine verdiği zararlar da artmıştır. Günümüzde sağlıklı besin maddeleri ile temiz içme ve kullanma suyundan sonra gereksinim duyulan ihtiyaçlardan biri de enerji ihtiyacıdır. Enerji üretimi küresel boyutta çevre sorunlarının artmasına neden olmuştur. Bu artışlar barajlar, hidroelektrik santralleri rüzgâr tribünleri gibi daha ucuz yenilenebilir enerji kaynaklarına yönlenmeleri beraberinde getirmiştir. Barajlar, temiz ve ucuz enerji üretimi sağlayan sistemlerden birisi olarak bilinmelerine rağmen gerek yapım aşamasında gerekse sonrasında antropojenik etkilere sebep olmaktadırlar.

Doğu Karadeniz Bölgesi'nde enerji ihtiyacı genel olarak hidroelektrik santrallerinden sağlanmaktadır. Doğu Karadeniz Bölgesi'nde yapılan ve yapımı devam eden en önemli hidroelektrik santralleri Çoruh Nehri üzerinde yer almaktadır. Yusufeli barajı bunlardan bir tanesidir. Yusufeli barajı, 1982 yılında tasarlanan "Çoruh Nehri Hidroelektrik Gelişme Planı” kapsamında planlanmıştır (Muluk vd. 2009). Baraj tamamlandığında maksimum su seviyesi $507 \mathrm{~m}$, minimum su seviyesi ise 499 m’ye ulaşacaktır (Encon 2006b). Barajın yapımı ile ilçe merkezi ve 18 köy sular altında kalacaktır. Alanda bazı yerleşim yerleri ve ulaşım ağının bir kısmı baraj rezervuar sahası içinde kalacağından, barajın neden olacağı değişimlerin bilinmesi alternatif ulaşım ağı ve yerleşim alanları için çözümler içerecek yönetim planlarının hazırlanması açısından önemlidir.

Bu çalışma ile Yusufeli Barajı yapım aşamasında ve yapım sonrasında ortaya çıkan antropojenik etkilerin belirlenmesi ve bu değişimlerin Peyzaj planlama ilkeleri kapsamında değerlendirilmesi amaçlanmaktadır. Ekosistemlerin ve su kaynaklarının korunması için sürdürülebilir kullanımının sağlanması açısından bilimsel çalışmaların yapılması, kullanım politikalarının geliştirilmesi ve alan kullanımları üzerinde yapılan değişimlerin izlenmesi doğal kaynaklar üzerinde yapılan baskıları azaltarak doğabilecek sorunların tespit edilmesinde yardımcı olacak ve çözüm önerilerinin geliştirilmesini sağlayacaktır.

\section{Materyal ve Yöntem}

\subsection{Materyal}

Çalışmanın materyalini, Karadeniz Bölgesi’nin Doğusunda kalan Artvin iline bağlı ve şehrin güneybatısında bulunan Yusufeli Barajı yapımı ile su altında kalan Yusufeli ilçe merkezi ve 18 köyü kapsayan alan oluşturmaktadır. Çalışmada yardımcı materyal olarak; Harita Genel Müdürlüğü tarafından üretilen Yusufeli İlçesi ile ilgili hava fotoğrafları, Yusufeli ilçesine ait halihazır haritalar, Harita Genel Müdürlüğü tarafından üretilen 1/25.000 ölçekli topoğrafik haritalar, Yusufeli Belediyesi'nden alınan eski yerleşim bölgesine ait imar planı ve yapılmakta olan yeni yerleşim bölgesi imar planı, DSİ tarafından üretilmiş olan yeni su kotu haritası, Trabzon Karayolları 10. Bölge Müdürlüğünden alınan yeni Artvin-Yusufeli ve yeni Artvin-Erzurum Karayolları haritası, Doğa Koruma ve Milli Parklar Artvin Şube Müdürlüğ̈̈nden alınan Çevre ve Yaban Hayatı Geliştirme Sahası Haritası, Artvin Orman Bölge Müdürlügünden alınan meşcere haritaları, Artvin İl Tarım Orman Müdürlüğü'nden alınan tarım ve hayvancılık raporları, Yusufeli ilçe Kaymakamlığı'ndan elde edilen ilçe faaliyet raporları, Artvin Valiliği il Çevre ve Orman Müdürlüğü tarafından hazırlanan Artvin Çevre Durum Raporu, Artvin il Kültür ve Turizm Müdürlüğ̈̈'nden alınan Yusufeli kültür varlıkları verileri, turizm master planı, Çevre ve Orman Bakanlığı tarafindan yapılmış olan ÇED planları kullanılmıştır.

\subsection{1. Çalışma Alanı}

Çalışma alanı Karadeniz Bölgesi'nin doğusunda yer alan Artvin iline bağlı Yusufeli ilçesinde yapılacak olan Yusufeli Barajı ve yakın çevresi olarak belirlenmiştir (Şekil 1a). Orta Çoruh havzasında yer alan Yusufeli ilçesi Artvin ilinin en büyük ilçesidir. İl merkezine $85 \mathrm{~km}$ uzaklıkta olan ilçe, $40^{\circ} 34^{\prime} 20^{\prime \prime}$ ve $41^{\circ} 07^{\prime} 24^{\prime}$ ' kuzey enlemleri, $41^{\circ} 09^{\prime} 25^{\prime}$ " ve $41^{\circ}$ 54'36" doğu boylamları arasında yer almaktadır (Yavuz Özalp vd. 2013). İlçe'nin doğuda Erzurum'un Oltu ve Olur ilçeleri, güney tarafında Erzurum'un Tortum, İspir ve Uzundere ilçeleri, batı bölgesinde de Rize ilinin Fındıklı, Ardeşen ve Çamlıhemşin ilçeleri, kuzeyinde ise Artvin merkez, Arhavi ve Murgul ilçeleri ile sınırı vardır.

Orta Çoruh Havzasında yer alan Yusufeli Barajı yapımı ile Yusufeli ilçe merkezi ve 3 köy tamamen, 18 köy ise kısmen su altında kalacaktır. Çalışma alanı sınırları belirlenirken, mevcut yapılacak barajı kapsayan Çoruh Nehri’nin kolları esas alınmıştır. Bu kollar 3 bölümden oluşmaktadır; Yusufeli Su Kavuşumu-Erzurum karayolu güzergâhı, Yusufeli Su Kavuşumu-Artvin Deriner Barajı karayolu güzergâhı ve Artvin Yusufeli ilçe merkezidir. 
Çalışmanın sistematik bir şekilde ilerlemesi için çalışma alanı söz konusu güzergâhlar dikkate alınarak Kılıçkaya, Öğdem ve Yusufeli bölgesi olacak şekilde üç bölgeye ayrılarak incelenmiştir. Dar vadi üzerinde konumlandırılan ilçenin topoğrafik yapısı oldukça engebelidir. İlçenin ortasından akan Çoruh Nehri ile Kaçkar ve Altıparmak Dağlarından kaynağını alan ve Yusufeli ilçe merkezinde Çoruh Nehri ile birleşen Altıparmak (Barhal) Çayı önemli su kaynaklarıdır. Yusufeli bölgesi, kuzeyden Altıparmak ve Kaçkar Dağları, güneyden ise Mescit Dağlarının doğu uzantıları ile sınırlandırılmıştır. İlçenin yüzölçümü $2214 \mathrm{~km}^{2}$ dir. Yusufeli'nin rakımı 560 metre, yüzölçümü $2327 \mathrm{~km}^{2}$ dir. İlçenin yüzey şekillerini genellikle doğu-batı doğrultusunda uzanan dağlarla, bu dağları birbirinden ayıran vadiler meydana getirir. İlçe; Ahalt (Evren), Kazahora (Kazım Karabekir), Vecanfet (Hasanağa), Minathev (Erdemler) ve Kananet mahallelerinden oluşmaktadır (Karabulut 2007). Yusufeli Barajının yapılması ile tamamen veya kısmen su altında kalacak köyler; Alanbaşı Köyü, Arpacık Köyü, Bahçeli Köyü, Bostancı Köyü, Çeltikdüzü Köyü, Çevreli Köyü, Darıca Köyü, Dereiçi Köyü, Irmakyanı Köyü, Küplüce Köyü, Kılıçkaya Beldesi, Kınalıçam Köyü, Morkaya Köyü, Mutlugün Köyü, Sebzeciler Köyü, Tekkale Köyü ve Yeniköy’den oluşmaktadır (Şekil 1b).

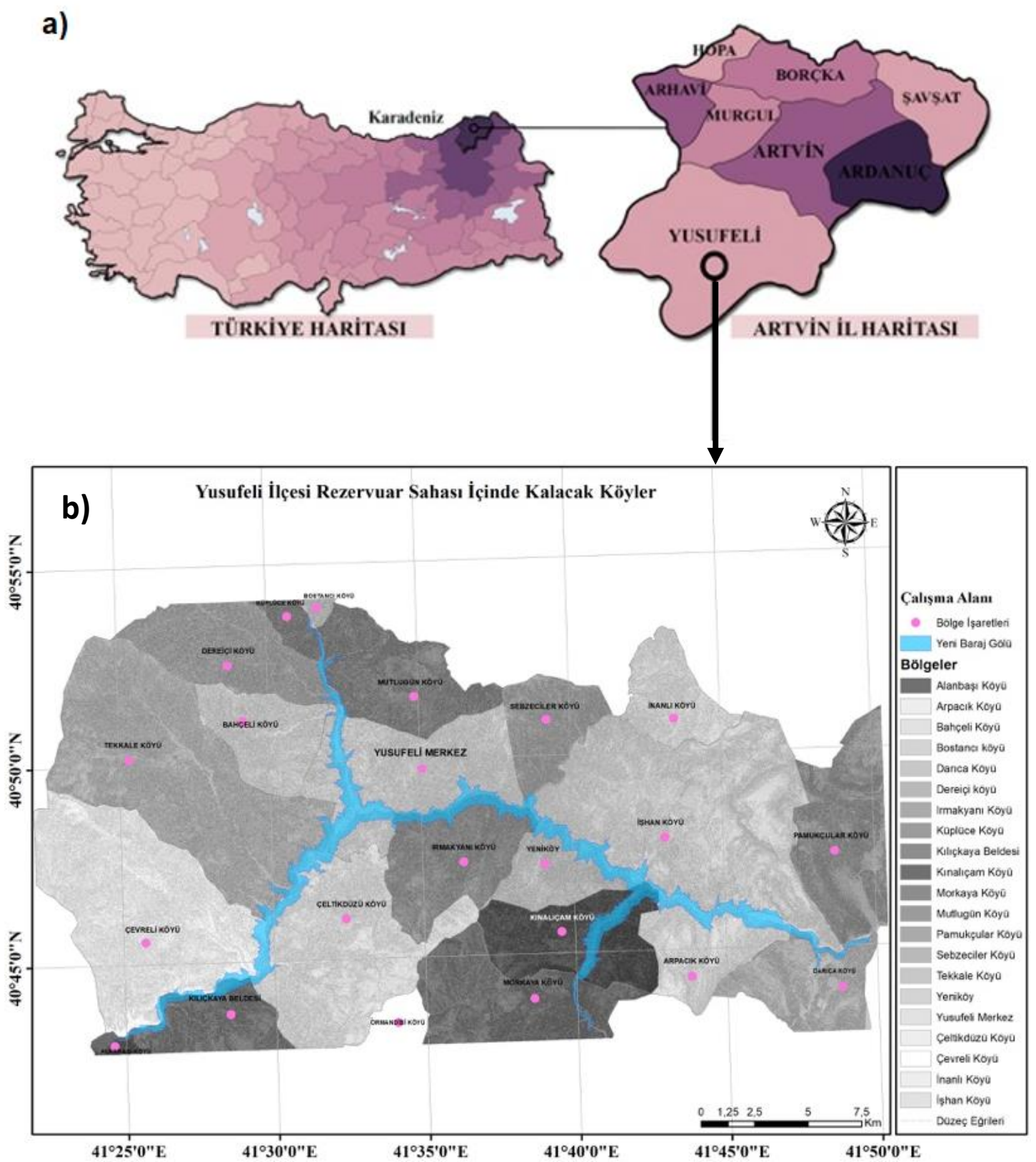

Şekil 1: a) Çalışma alanının coğrafi konumu, b) Yusufeli barajı rezervuar sahası içinde kalan köyler

Topoğrafik yapı: İlçenin rakımı 565m'dir. Yüksek dağlık alanları olan ilçenin en yüksek noktası olan Kaçkar Dağları 3932m yüksekliğindedir. Çoruh Nehri derin vadi içerisinde akmakta dağlık engebeli bir arazi bölgeye hâkim olmaktadır. Çoruh Nehri'nin tabanında dar alanlara sıkışmış düzlükler yerleşim alanları ve tarım alanı olarak kullanılmaktadır. 
Uzunluğu $1520 \mathrm{~km}$ olan bu tabandan sonra dik vadilerle arazi oldukça engebeli bir yap1 göstermektedir. Barhal Çayı vadisi 40 km uzunluğunda Yusufeli'den sonra gelen ikinci derin vadi özelliğindedir (Demirel 1997). Şekil 2'de Yusufeli ilçesinin yükseklik, eğim ve bakı haritaları verilmiştir.
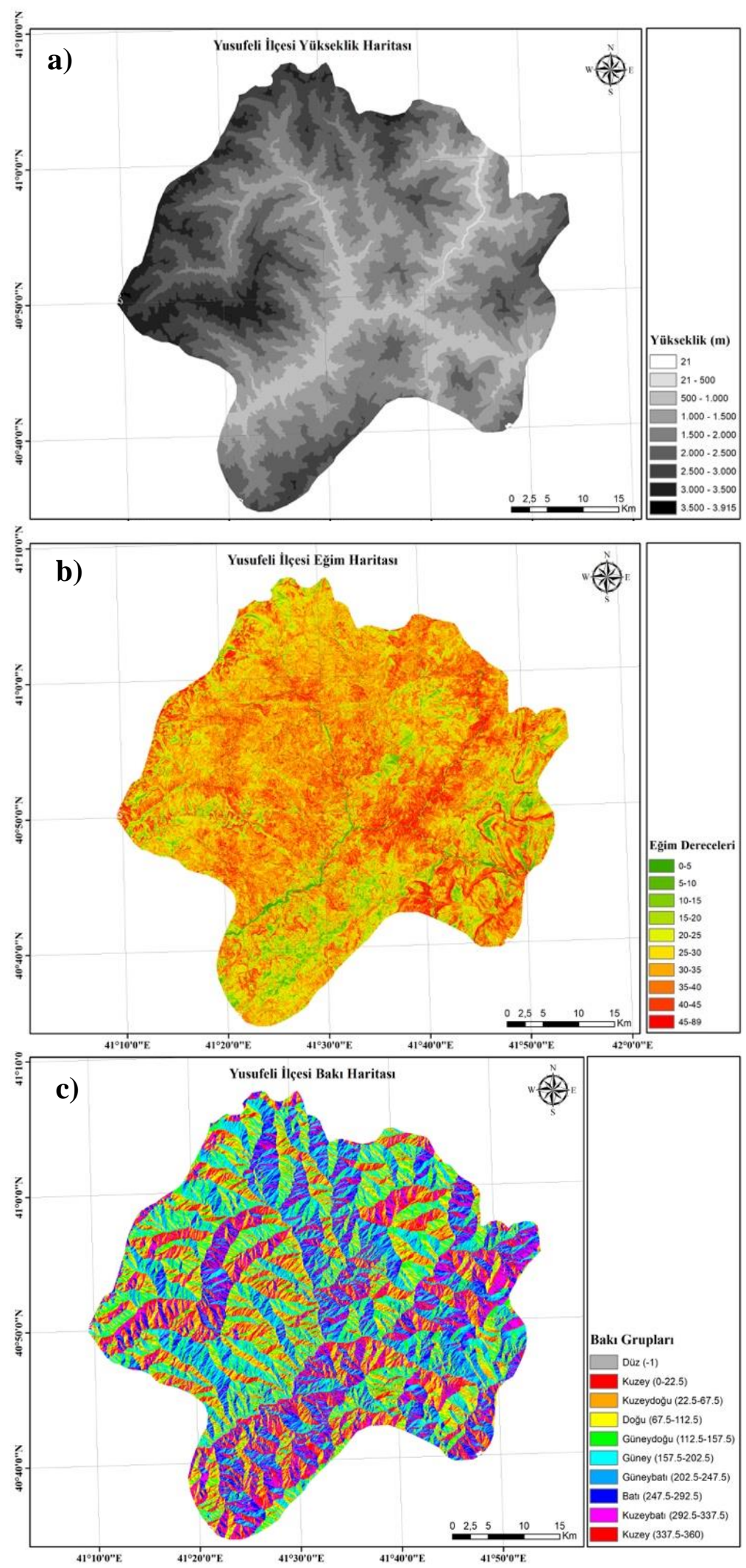

Şekil 2: Yusufeli Ilçesinin a) yükseklik, b) eğim ve c) bakı haritası 
İklim özellikleri: Çoruh Nehri yakınlarında yazlar sıcak ve kurak, kışlar ılık ve yağışlı geçerek Akdeniz iklimini andırır. Vadinin yüksek kesimlerinde karasal iklim hüküm sürer. Yazlar serin, kışlar soğuk ve yağışlıdır. Yağışlar genelde ilkbahar sonu ve yaz başlarında görülür (Uzun 2017). İklim yönünden geçiş konumunda olan ilçenin yıllık ortalama yağış miktarı $537 \mathrm{~mm}$ ve yıllık ortalama sicaklığ 1 ise $9.2^{\circ} \mathrm{C}$ 'dir (URL-1 2020)

Hidrolojik durum: Yusufeli ilçesi göller, akarsular ve yeraltı suları bakımından zengindir. İlçede Çoruh Nehri ve Barhal Deresi önemli yüzey suyu olmakla birlikte Bıçakçılar Deresi, Tekkale Deresi, Yüncüler Deresi bulunmaktadır. Bunun dışında 2000 m yükseltilerde buzul aşındırması sonucu oluşmuş Tatlı Göl, Deniz Gölü, Damla Göller, Yeşil Göller gibi pek çok buzul gölü mevcuttur. Çoruh Nehri, Bayburt’tan doğup Erzurum İspir ilçesinden sonra Artvin ili sınırlarında yoluna devam ederek Gürcistan Batum'dan Karadeniz'e dökülür. $431 \mathrm{~km}$ yol kat ederek sarp kayalıklardan derin vadilerden geçer. Oldukça hızlı akan nehir yıllık ortalama 6,3 milyar $\mathrm{m}^{3}$ lük akış hacmine sahiptir. Nehir üzerinde 10 adet baraj ve yan kollarda 17 adet baraj ve nehir tipi HES olmak üzere toplamda 27 adet tesis yapılması planlanmıştır. Yusufeli Barajının ana su kaynağı, Çoruh ve Barhal Çayı'nın birleştiği bir noktada 550 m rakımda konumlandırılmıştır. Yukarı Çoruh Havzası içerisinde; Arkun Barajı, Aksu Barajı, Güllübağ Barajı, İspir Barajı ve Laleli Barajı bulunmaktadır. Arkun barajı Artvin ili sınırları içerisinde yer alırken diğer barajlar Erzurum il sınırları içerisinde yer almaktadır (Küçükbaşol 2015).

Doğal bitki örtüsü: Çoruh Vadisi, Akdeniz Kalıntı Ekosistemi ile bütün Kafkasya Ekolojik Bölgesi içerisinde bir eşi daha bulunmayan bir özellik göstermektedir. Buzul dönemlerinde yaşanan soğuma sırasında buzulların güneye hareket etmesiyle buradaki bitki örtüsü de değişip daha soğuk kuşakların orman örtüsü alanda hâkim olmuştur. Ancak Çoruh ve Barhal Vadisi yarattıkları sıcak mikroklima etkisi ile bu alanın bitki örtüsünün korunmasını sağlamıştır. Bu yüzden de bugün bu bölgede Akdeniz'e ait türlerden oluşan bir bitki örtüsü ve ekosistem görülmektedir (Muluk vd. 2009, Demirel 1997). Çoruh Vadisi'nin ve özellikle Yusufeli bölgesinin tür çeşitliliği olarak oldukça zengin potansiyele sahip olduğu pek çok çalışma ile ortaya konulmuştur. Alanın tür zenginliği hakkında Muluk vd. (2009), Demirel (1997), Kurt ve Balkız (2011), Aksu (2015), Açıkgöz (2015), Eminağaoğlu ve Tilki (2015)'nin yapmış olduğu çalışmalar incelenmiştir. İklimin ve arazi yapısının bu çeşitlilikte etkili olduğu bilinmektedir Çoruh Vadisi tabanından yükseklere doğru görülebilecek formasyonlar; dere vejetasyonu, karışık Akdeniz çalılıkları, Carpinus-Quercus çalılığı, Quercus-juniperus çalılıkları, Carpinus, Quercus, Juniperus, Picea, Pinus sylvestris ormanları, Pice, Pinus sylvestris ormanlar1, Juniperus seyrek ormanları, alpin çayırlar şeklinde görülmektedir.

Fauna: Yusufeli ilçesi fauna yönünden oldukça zengin tür çeşitliliği içermektedir. Yaban Keçisi (Capra aegagrus) 500-2500 m yüksekliklerde, Çengel Boynuzlu Dağ Keçisi (Rupicapra rupicapra) ise ortalama $1800 \mathrm{~m}$ üzerinde yaşamaktadır (Uçarlı 2016). Dağ keçilerinin yanı sıra çalışma alanı boyunca kara ve su faunası görülmektedir. Bölgenin önemli potansiyellerinden birisi kelebek tür çeşitliliğidir. Büyük memeli türleri; Karaca (Capreolus capreolus), Kızıl Geyik (Cervus elaphus), Yaban Domuzu (Sus scrofa), Çakal (Canis aureus), Kurt (Canis lupus), Vaşak (Lynx lynx), Ayı (Ursus arctos), Porsuk (Meles meles), Susamuru (Lutra lutra) olmak üzere bölgede varlığı kesin olan ve tahmin edilen türlerdir. Bunun dışında pek çok küçük memeli türü bulunmaktadır. Nal burunlu yarasa ve küçük nal burunlu yarasa korunması gerekli önemli türler arasında yer almaktadır. Kafkasya bölgesi yırtıcı kuş türleri için geçiş noktasındadır. Çalışma alanı bu yönden de zengin tür çeşitliliği ile dikkat çekmektedir (Göktürk vd. 2011).

Toprak yapısı: Sarp kayalıkların yüksek eğimlerin olduğu yerlerde toprak bulunmamaktadır. Sahadaki azonal topraklar, alüviyal topraklar, kolüviyal topraklar ve litosollerden oluşan genç topraklardan meydana gelmektedir. Birikinti konileri, birikinti yelpazeleri, vadi tabanları, heyelan sahaları ve eğimli yamaçların etekleri boyunca yayılış gösteren bu topraklarda olgun bir horizona rastlanmamakta ve genelde A-C horizonu görülmektedir (KHGM 2000). Yusufeli ilçesi arazi kullanım kabiliyet sınıfları Şekil 3’te verilmiştir. Bu sınıflandırma sistemi yeryüzündeki tüm arazileri 8 kategoriye ayırarak, I. sınıf arazi en kaliteli toprak sınıfı olmak üzere ilk dördünü işlemeli tarımsal üretime uygun araziler, diğer dört sınıfı da işlemeli olarak tarımsal üretime uygun olmayan araziler olarak sınıflandırır. Şekil 3’te de görüldüğü gibi ilçe toprakları AKK sınıflandırmasında ağılıklı olarak IV ve V. sınıf arazilerinden oluşmaktadır. Tarıma en elverişli olan I. sınıf arazi grubu se Çoruh Nehri kıyılarında görülmektedir.

\subsection{Yöntem}

Yapılan bu çalışmada baraj öncesi alan özellikleri belirlenerek baraj yapımında ve sonrasında olabilecek antropojenik etkilerin ortaya konulması hedeflenmiştir. Çalışma büro ve arazi çalışmaları olacak şekilde iki aşamada yürütülmüştür. İlk aşamada; barajlar, baraj yapımları ile ortaya çıkan değişimler, toplumsal yaklaşımlar, Türkiye'nin enerji ihtiyacı, enerji politikaları, yasa ve yönetmelikler ve ÇED raporları, basına yansıyan haberler, çalışma alanı doğal, kültürel peyzaj deseni vb. hakkında literatür taramaları yapılmıştır. Bu aşamada pek çok yerli ve yabancı kaynaklar taranmıştır. Çalışmanın ikinci aşamasında ise; Yusufeli barajına ve alana ait veriler toplanmıştır. Bu aşamada sayısal veriler temin edilmiştir. Hava fotoğrafları, 1/25000 ölçekli topoğrafik haritalar, Yusufeli ve Artvin Belediyeleri ile Çevre Şehircilik ìl Müdürlüğü'nden elde edilen eski ve yeni yerleşim imar planları, Artvin Orman Bölge Müdürlügü̆'nden alınan meşcere haritaları, Artvin İl Tarım Orman Müdürlüğünden alınan tarım ve hayvancılık raporları, ÇED raporları temin edilmiştir. 


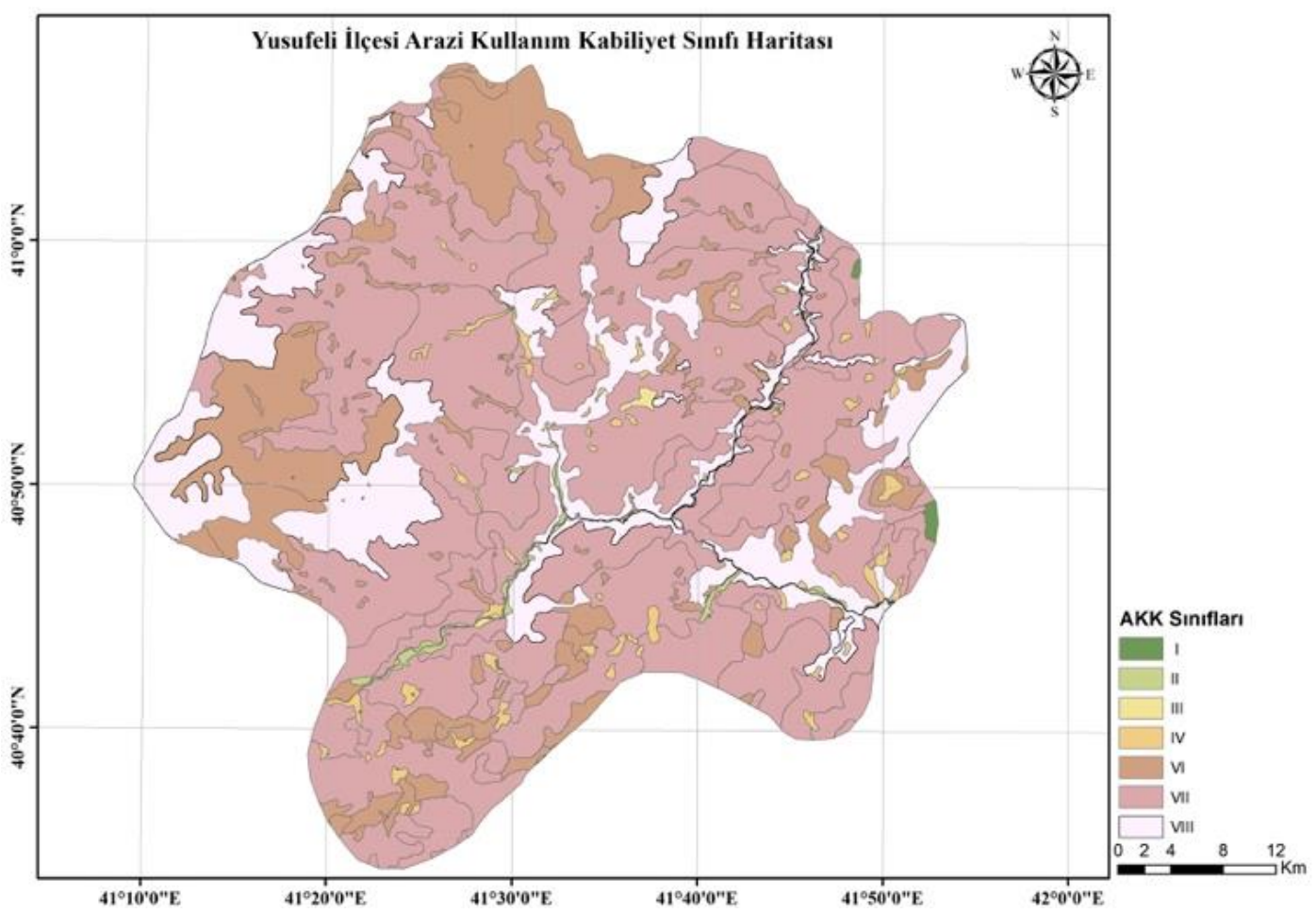

Şekil 3: Yusufeli ilçesi arazi kullanım kabiliyeti haritası

Kültür varlıkları hakkında kayıtlar incelenmiştir. Alan değişimlerinin gözlemlenebilmesi için çalışmanın başlangıç aşamasından itibaren farklı zamanlarda arazi gözlemleri yapılmış ve dijital olarak kaydedilmiştir. Aynı zamanda yöre halkı ile baraj ve günlük yaşam üzerine söyleşiler yapılarak halkın bakıș açısı belirlenmeye çalışılmıştır. Yeni yerleşim alanı için yapılan çalışmalar aşama aşama gözlemlenmiş ve kaydedilmiştir. Alan değişimlerinin sistemli bir şekilde ortaya konulabilmesi için arazi kullanım şekilleri incelenerek hidrolojik yapı, ulaşım, yerleşim, açık yeşil alanlar, korunan alanlar ve kültür varlıkları şeklinde veri setleri oluşturulmuştur. Veri setlerinin sayısallaştırılmasında ArcGIS 10.2 yazılımı kullanılmıştır. Mevcut durum ve baraj sonrası oluşan; hidrolojik yapı, tarım, orman, yerleşim, ulaşım, yeşil alanlar ve korunan alanlara ait alansal değişiklikler karşılaştırılmıştır. Çalışmanın son aşamasında elde edilen veriler ışığında değerlendirmeler yapılmıştır. Oluşan ve oluşacak olan antropojenik etkiler ve sonuçları tartışılarak sürdürülebilir alan kullanımları için önerilerde bulunulmuştur.

\section{Bulgular ve Tartışma}

Yusufeli Barajı yapım aşamasında ve sonrasında oluşacak antropojenik etkilerin belirlenmesi için, kırsal alan ve yerleşim alanına ait değişimler incelenmiştir. Yusufeli kırsal alan deseni, toprak kabiliyet sınıfları, hidrolojik yapı, ormanlık alanlar, korunan alanlar ve kültür varlıkları, ilçe merkezi imar planı (açık yeşil alanlar, alan kullanımları) topoğrafya, eğim, yükseklik, sirkülasyon değişimleri incelenmiştir (Şekil 4a). Yusufeli barajının su tutması ile su altında kalacak bölgeler Şekil 4b'de verilmiştir.

Barajın su tutmaya başlamasıyla beraber Kılıçkaya bölgesindeki "kum alanlarının" tamamı, "göl, bent, baraj ve nehir" alanlarının \%78'i, "kayalık ve taşlık" alanların \%35'i, "ziraat ve iskan” alanların \%32'si, “tarım” alanlarının \%17'si su altında kalacaktır. Öğdem bölgesine ait alan verileri incelendiğinde, Yusufeli barajının su tutmaya başlamasıyla birlikte K1lıçkaya bölgesine benzer olarak, "göl, bent, baraj ve nehir" alanlarının \%55'i, "ziraat ve iskan" alanlarının \%40'ı ve "ziraat ve orman toprağı" alanlarının ise \%13'ü su altında kalacaktır. Yusufeli ilçe merkezinde diğer bölgelerden farklı olarak "iskan alan ve mezarlık" alanların \%39'u, "göl, bent, baraj ve nehir" alanlarının \%26'sı ve "tarım" arazilerinin $\% 17$ 'si, barajın su tutmaya başlamasıyla birlikte su altında kalacaktır. 

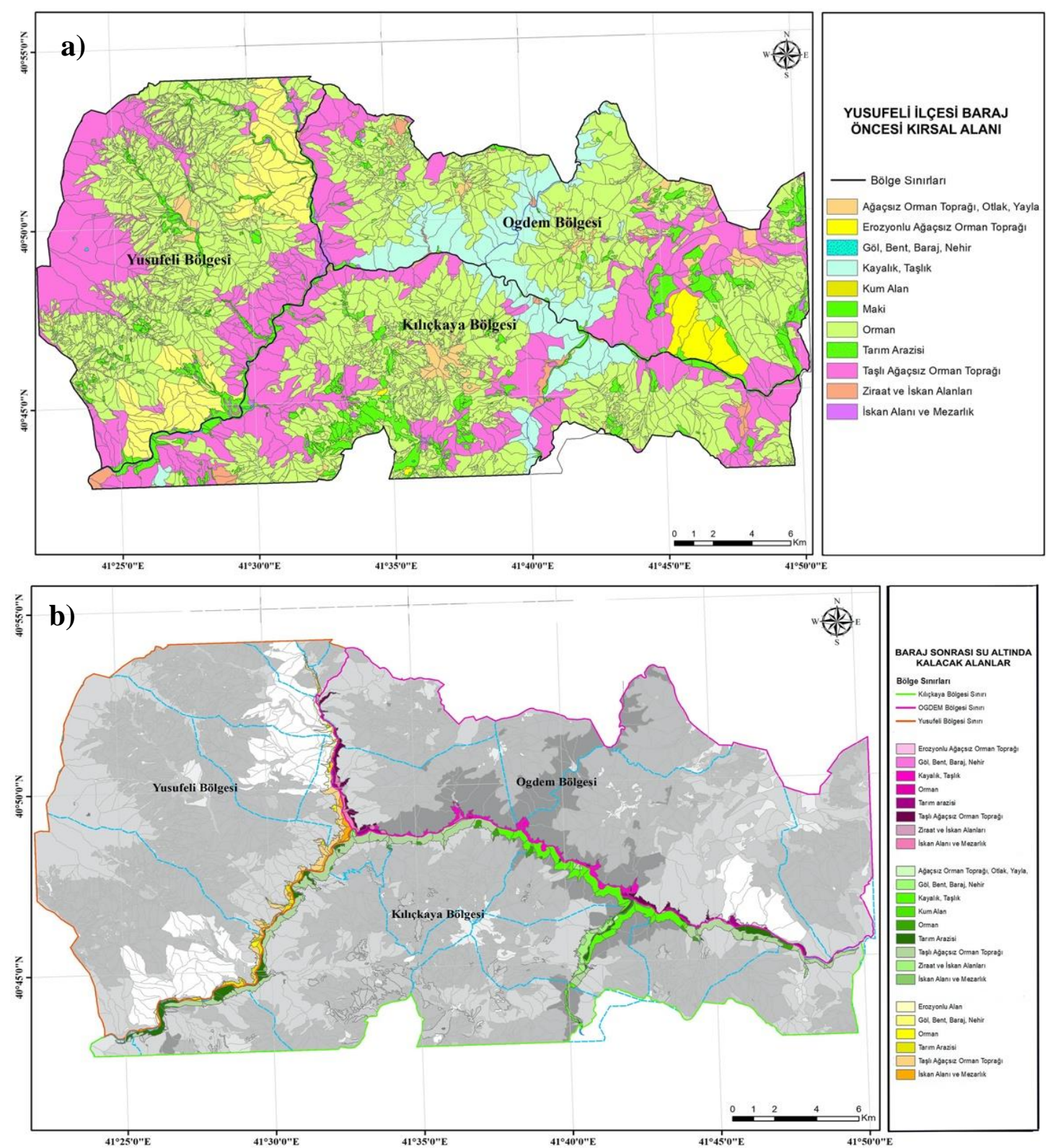

Şekil 4: a) Çalışma alanındaki mevcut arazi kullanımı b) Yusufeli Barajı sonrası su altında kalacak alan kullanımları

Çalışma alanında VII. sınıf arazilerin en yüksek (45320ha), I. sınıf arazilerin ise en düşük orana sahip alanlar olduğu (289 ha) belirlenmiştir. Tarıma uygun araziler toplam alanın \%2.03'ünü oluşturmakta ve çok önemli bir kısmı baraj rezervuar alanı içinde kalmaktadır (Şekil 5 a, b). AKK sınıflarının dağılımları, hali hazırdaki ve baraj sonrası durumları Tablo 1'de verilmiştir. Yapılan değerlendirme sonucunda I. sınıf arazilerin \%100’ünün, II. sınıf arazilerin \%69'unun, III. sınıf arazilerin \%81'inin, IV. sinıf arazilerin \%7'sinin, VI. sinıf arazilerin \%1'inin ve VII. sinıf arazilerin \%1'inin su altında kalacağ1 görülmüştür.

Tablo 1: Araştırma alanındaki arazi kullanım kabiliyet sınıflarının alanları

\begin{tabular}{|c|c|c|c|c|}
\hline $\begin{array}{c}\text { Arazi kullanım } \\
\text { kabiliyet sınıfları }\end{array}$ & $\begin{array}{c}\text { Alan } \\
\text { (ha) }\end{array}$ & $\begin{array}{c}\text { Toplam araziye } \\
\text { oranı (\%) }\end{array}$ & $\begin{array}{c}\text { Su altında kalacak } \\
\text { alan (ha) }\end{array}$ & $\begin{array}{c}\text { Su altında kalacak } \\
\text { alan (\%) }\end{array}$ \\
\hline I & 289.4 & 0.43 & 289.4 & 100.00 \\
\hline II & 1010.17 & 1.50 & 705.23 & 69.81 \\
\hline III & 105.15 & 0.10 & 85.71 & 81.51 \\
\hline IV & 1716.30 & 2.50 & 127.57 & 7.43 \\
\hline VI & 3236.52 & 4.80 & 38.56 & 1.19 \\
\hline VII & 45320.41 & 68.40 & 566.16 & 1.25 \\
\hline Toplam & $\mathbf{6 6 2 1 9 . 6 2}$ & & $\mathbf{3 5 2 4 . 9 3}$ & \\
\hline
\end{tabular}



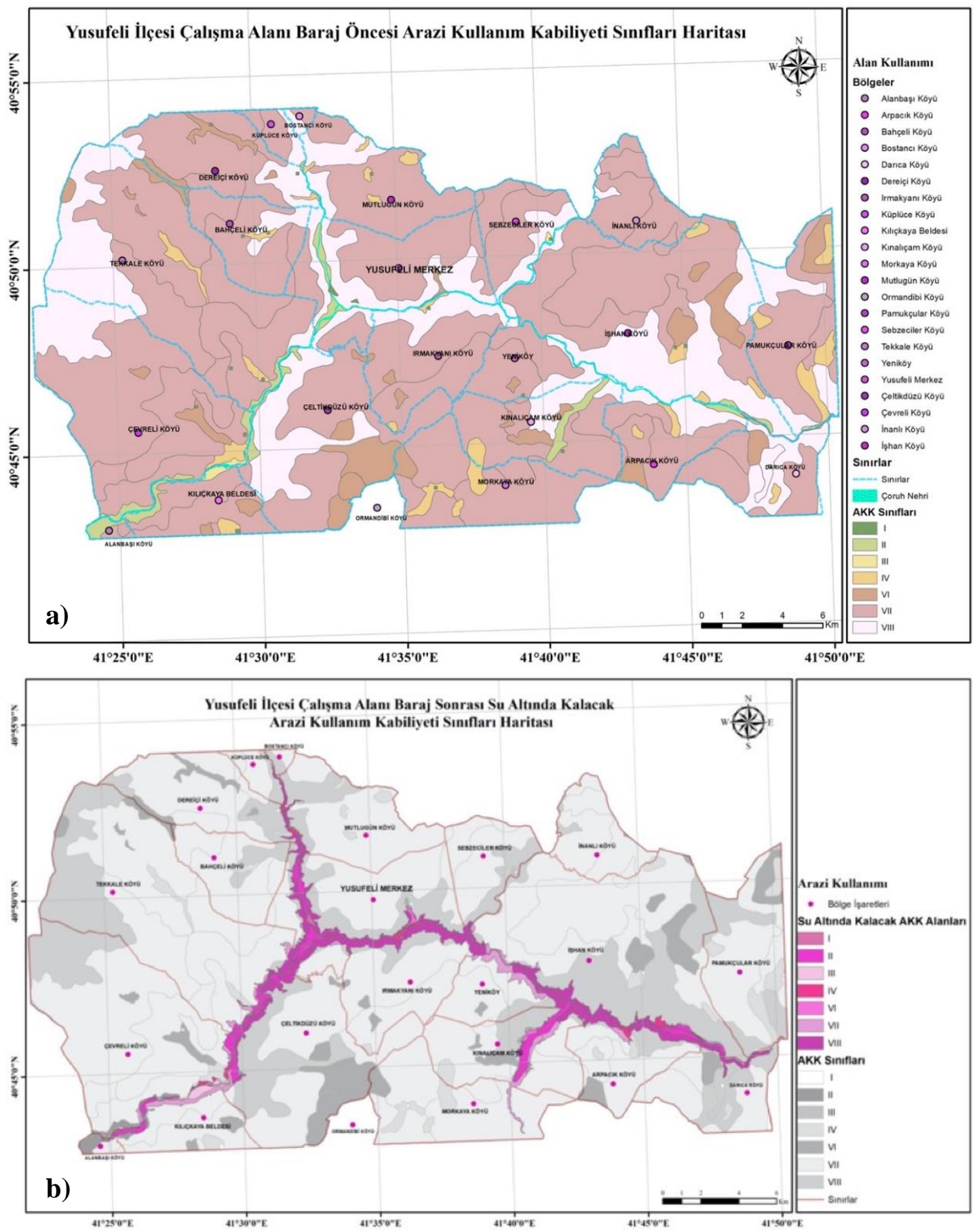

Şekil 5: a) Yusufeli ilçesi baraj öncesi AKK sınıfları, b) Yusufeli Barajı sonrası su altında kalacak alanların AKK haritası

Yapılan planlarda, kısmen su altında kalacak köylerdeki bazı hanelerin yalnızca arazi kaybına maruz kalacağı, bazılarında ise hem yapı hem arazi kaybının olacağı görülmektedir. Yusufeli ilçesi belirlenen çalışma alanında toplam 4327,3 ha özel mülkiyet alanı bulunmaktadır. Yapılan hesaplamalara göre baraj yapımı tamamlandıktan sonra ise bu alanın 854,1 ha kısmı yeni baraj gölünün altında kalacaktır.

Hidrolojik yapı değişimi: Çoruh Nehri 1420 m'lik toplam düşü yüksekliği ve yıllık 6.3 milyar m³'lük akış hacmi ile Türkiye'nin önde gelen akarsularından birisidir. Yusufeli Barajının kurulu gücü 558MW ve yıllık enerji üretimi 1 milyar 888 milyon KWh/yıl'dır. Yapılan barajın altı yüz bin kişinin enerji ihtiyacını karşılaması planlanmaktadır. Barajın oluşacak taşkın risklerini azaltacağı ifade edilmektedir (Şekil 6). 


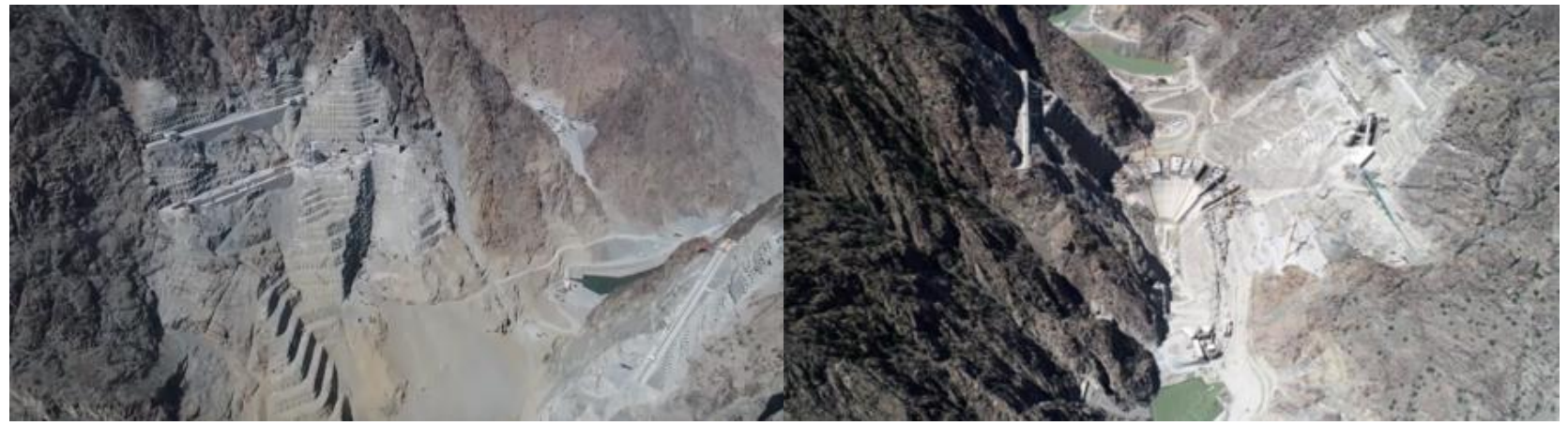

Şekil 6: Yusufeli barajı yapım aşaması görüntüleri (Foto: Artvin DSI 26. Bölge Müdürlüğü IHA görüntüleri)

ÇED raporuna göre (Encon 2006b) normal işletme koşullarında baraj gövdesindeki su seviyesi en yüksek $710 \mathrm{~m}$ en düşük $670 \mathrm{~m}$, baraj gölünün toplam uzunluğu ise $60 \mathrm{~km}$ baraj gölünün yüzey alan $33 \mathrm{~km}^{2}$ olacağı ifade edilmiştir. Yusufeli Barajı su tuttuktan sonra yaklaşık $4381386 \mathrm{~m}^{2}$ ’lik su yüzeyi oluşacaktır (Şekil 7).

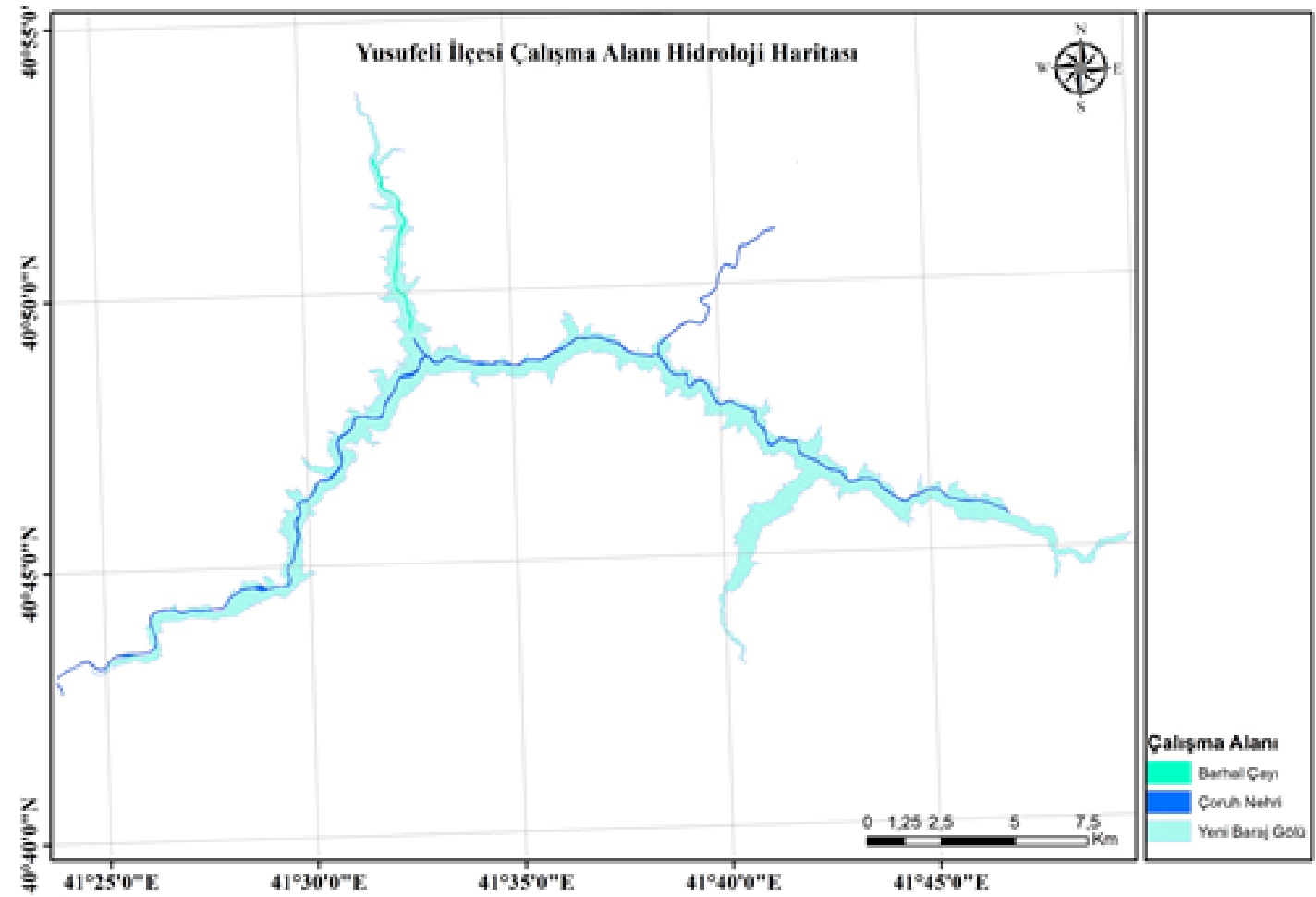

Şekil 7. Yusufeli Barajı sonrası oluşacak su yüzeyi

Su yüzeyleri, kentler için estetik değerlerinin yanı sıra iklim açısından yaşam alanlarını olumlu etkilemektedirler (Irmak vd. 2018). Yusufeli Barajı ile oluşan su yüzeyindeki bu ciddi artış mikroklima oluşmasına sebep olacaktır. Özellikle vadi alanın nemlilik oranı artacaktır. Sıcaklıkta da değişimler gözlemlenecektir. Kaya (2011)'e göre yüksekliğin $100 \mathrm{~m}$ artmasına bağlı olarak sıcaklığın $0.4-0.6{ }^{\circ} \mathrm{C}$ düşmesi öngörülmektedir. Yükseklik açısından yeni ve eski yerleşim alanları en düşük kotlarına göre karşılaştırıldığında eski yerleşimin en düşük kotunun $560 \mathrm{~m}$ olduğu yeni yerleşim alanının ise en düşük kotunun $760 \mathrm{~m}$ olduğu görülmüştür. Bu nedenle yeni yerleşim alanında yüksekliğe bağlı olarak sıcaklıkta 0.8-1.2 derece arasında düşüş beklenmektedir. Yine arazi çalışmaları sırasında gözlemlenen en olumsuz iklim parametresi rüzgar olmuştur. Özellikle yeni yerleşim alanının ikinci bölgesi olan Yansıtıcılar kısmının oldukça rüzgârlı olduğu görülmüştür. Kentsel ısı adalarının olumsuz etkilerini azaltmak için yerleşim alanlarının mikroklima özelliklerinin bilinmesi önemlidir (Irmak ve Yilmaz 2019).

Yusufeli ilçesi yerleşim deseni: Yusufeli barajının bitimi ile birlikte Yusufeli ilçe merkezi, Kınalıçam, Irmakyanı ve Yeniköy beldeleri tamamen; 18 köy ise kısmen sular altında kalacaktır. Yusufeli barajının su tutması sonucu yerleşim deseni açısından görülecek en büyük değişim Yusufeli İlçe merkezinde olacaktır. 2008 yllına ait bakanlar kurulu kararına göre ilçe merkezinin taşınması kararı alınmıştır (Şekil 8). 

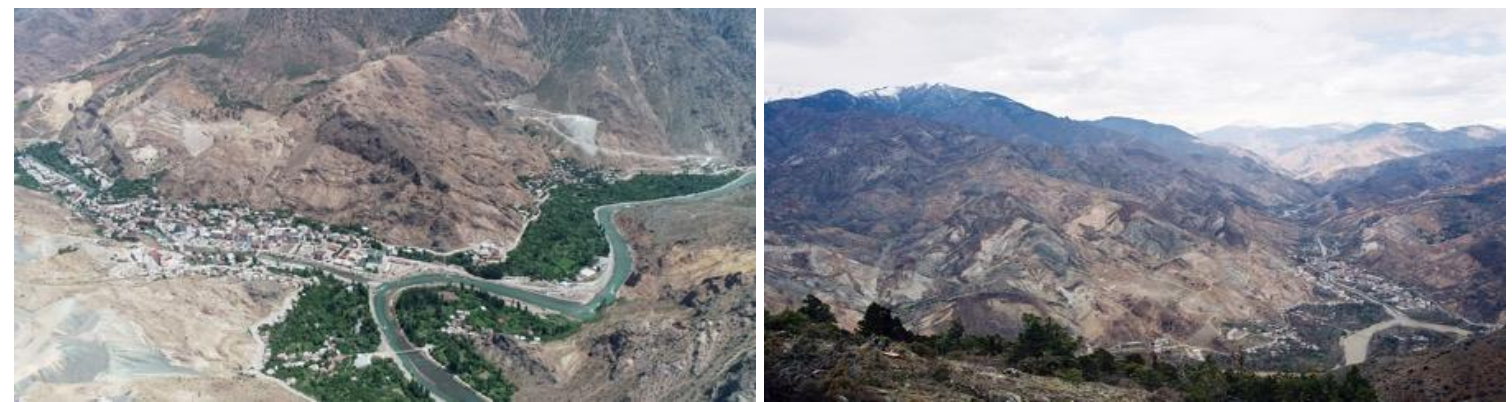

Şekil 8: Yusufeli İlçesine ait görseller

Artvin Valiliğinin koordinatörlüğünde ilçe merkezinde 911, köylerde 1611 hane reisi ile anket yapılmıştır ve anket çıkan sonuçlara göre 'Yansitıcılar Mevkii' uygun görülmüştür (Türk ve Erkan 2018). Alan eski ilçe merkezine kuş uçumu 1 km. uzaklıkta olup tamamen devlet mülkiyetindeki arazilerden oluşmaktadır. Şekil 9'de eski ve yeni yerleşimlerin bir arada olduğu fotoğraflar yer almaktadır.
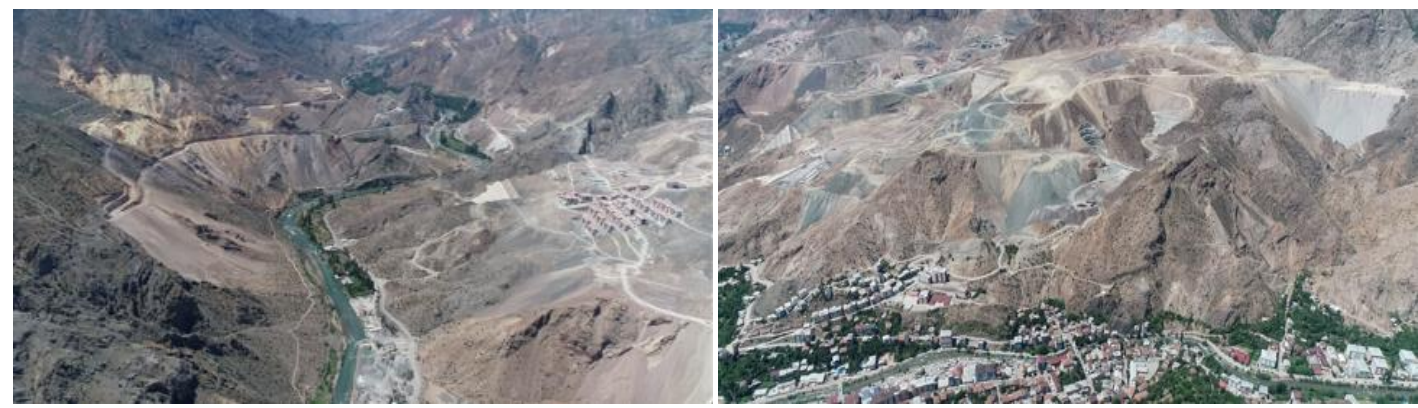

Şekil 9: Yusufeli yeni ve eski yerleşim alanlarına ait görseller (Foto: Artvin DSi 26. Bölge Müdürlüğü IHA görüntüleri)
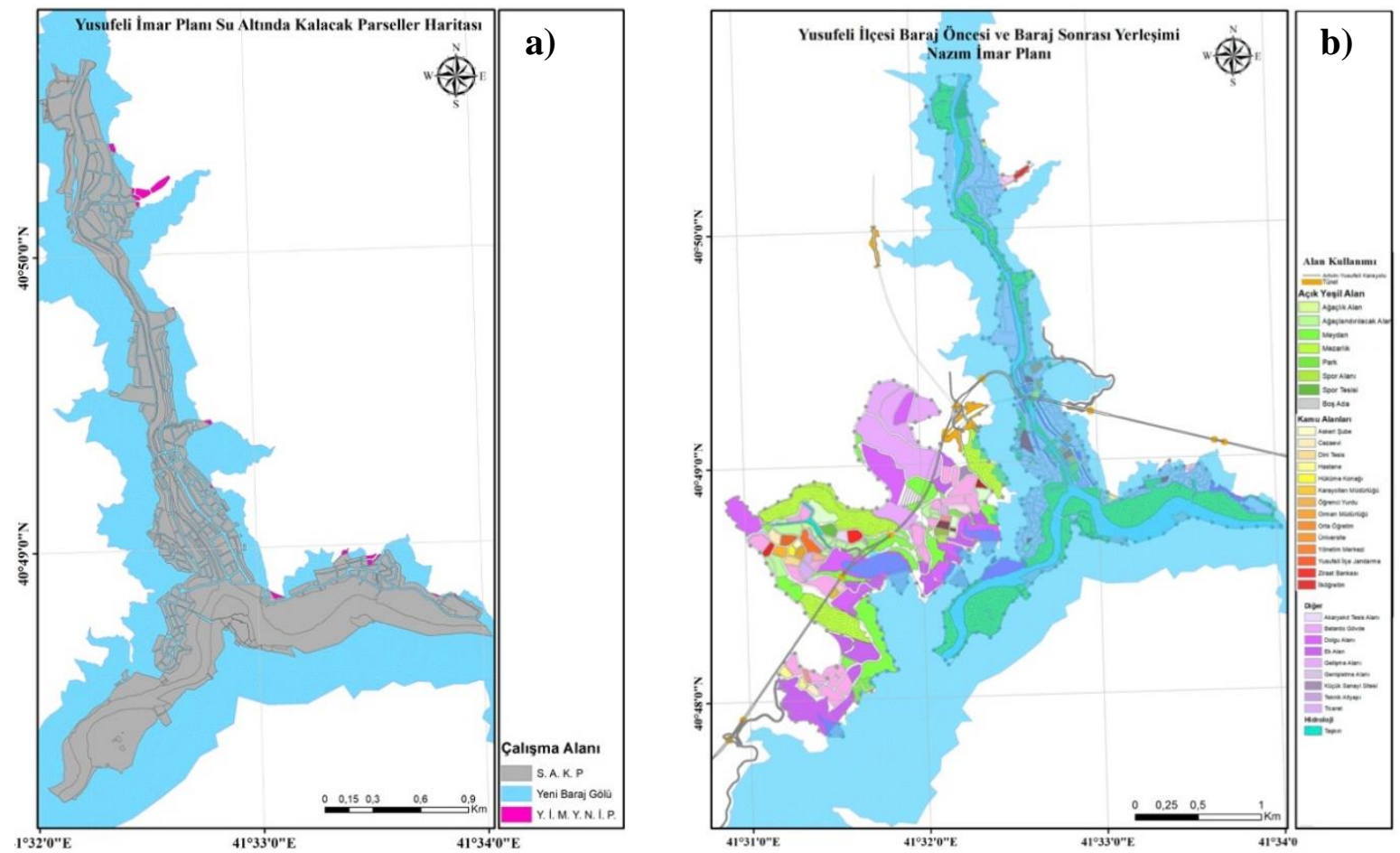

Şekil 10: a) Yusufeli İlçe yerleşimi baraj sonrası durumu, b) Yusufeli yeni ilçe merkezi baraj sonrası su tutma durumu

Yusufeli'nin baraj yapım çalışmalarından en fazla etkilenen kısım ilçe merkezidir. Çoruh Nehrinin iki yanında dar bir alanda yerleşen Yusufeli ilçe merkezinin tamamı, Yusufeli barajının su tutmaya başlamasıyla birlikte su altında kalacaktır (Şekil 10a). Yeni yerleşim ve eski yerleşimin baraj sonrası durumu Şekil 10b'de verilmiştir. 
Yusufeli ilçe merkezinin eski yerleşim yerinin imar planındaki toplam alanı 186,9 ha olarak hesaplanmıştır. TOKİ'nin yapmış olduğu Çevre Şehircilik Bakanlığının onayladığı yeni yerleşim planı 213,3 ha'lık alanı kapsamaktadır. Planda kullanım alanı olarak, ilk etapta 75 ha'lık bir alan kurgulanmış daha sonra ek yapılarak yeni yerleşim kullanım alanı yaklaşık 150 ha'a çıkarılmıştır (Şekil $11 \mathrm{a}, \mathrm{b})$.
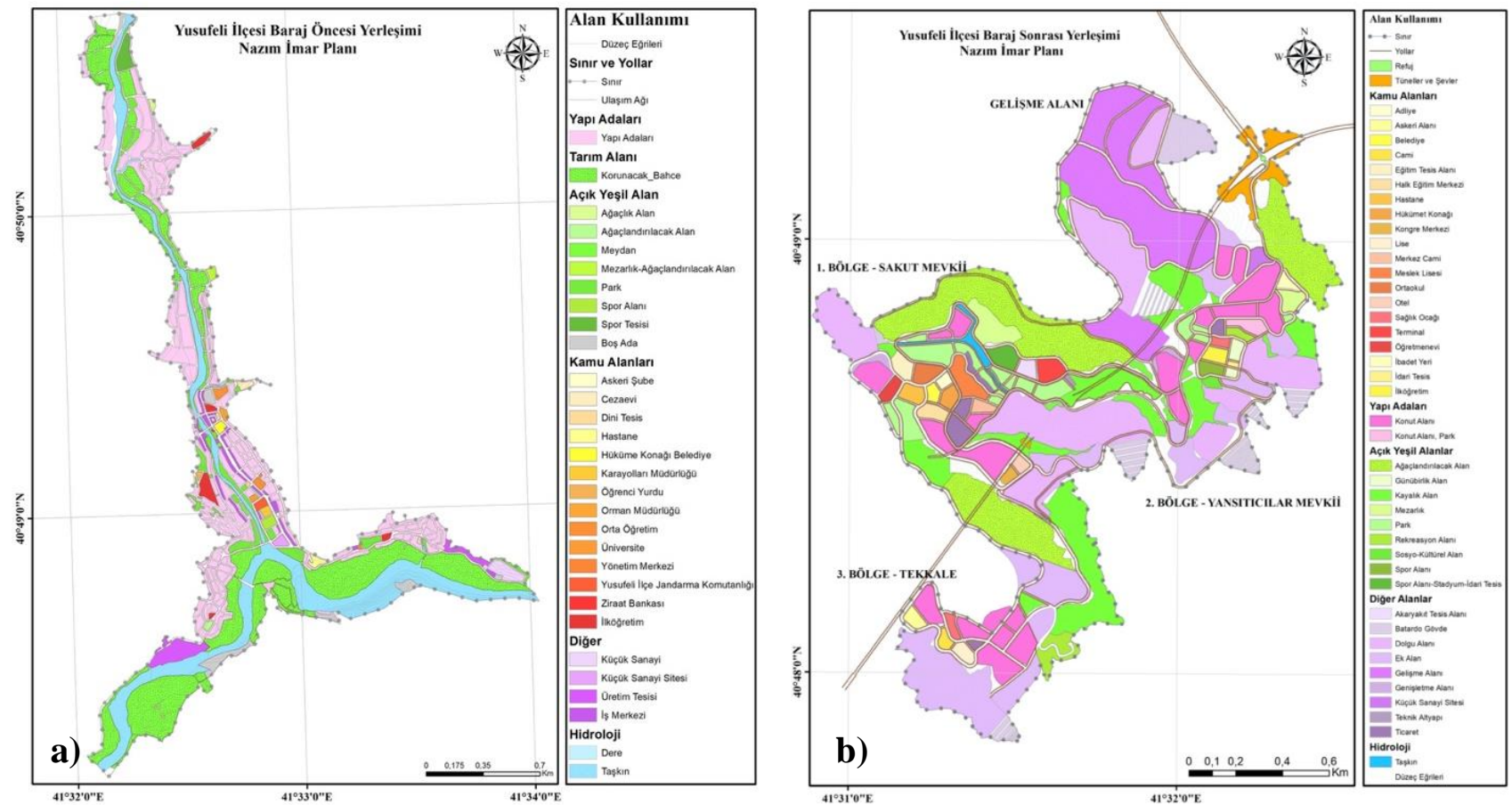

Şekil 11: a) Yusufeli ilçe merkezinin eski nazım imar planı, b) Yusufeli yeni ilçe merkezinin nazım imar planı

Yeni yerleşim alanı nazım imar planı incelendiğinde yerleşim planının 3 bölge halinde planlandığı, kamu alanlarının bir bölgede toplanmaya çalışıldığı görülmektedir. Eski yerleşim alanında kamu alanları için görülen arazi sıkıntısı yeni planlarda görülmemektedir. Konut alanları yoğun olarak II. ve III. bölgelerde toplanmış ve yaklaşık 1300 konutun yapılması planlanmıştır. Konut alanları toplamda 21,66 ha'lık bir alanda planlanmıştır. Yeni yerleşim alanının konut yapısı incelendiğinde bitişik bloklar halinde yapılan konutların $2+1$ ve $3+1$ olarak yapıldığı görülmüştür. Genellikle 5 katlı yapılan binaların çevre düzenleme çalışmalarının da yapılacağı ifade edilmektedir (Şekil 12). Yeni yerleşim alanı değerlendirilirken yalnızca sayısal veriler açısından değerlendirilmiştir. Oysaki alt yapı problemleri, peyzaj tasarımları, kentsel donatıları vb. kentsel konfor standartlarının değerlendirildiği herhangi bir planlama verisine ulaşılamamıştır. Yerleşim alanlarında kullanılan her türlü döşeme malzemelerinin estetik olduğu kadar termal kontrol yönünden de önemli olduğu unutulmamalıdır (Irmak vd. 2017).

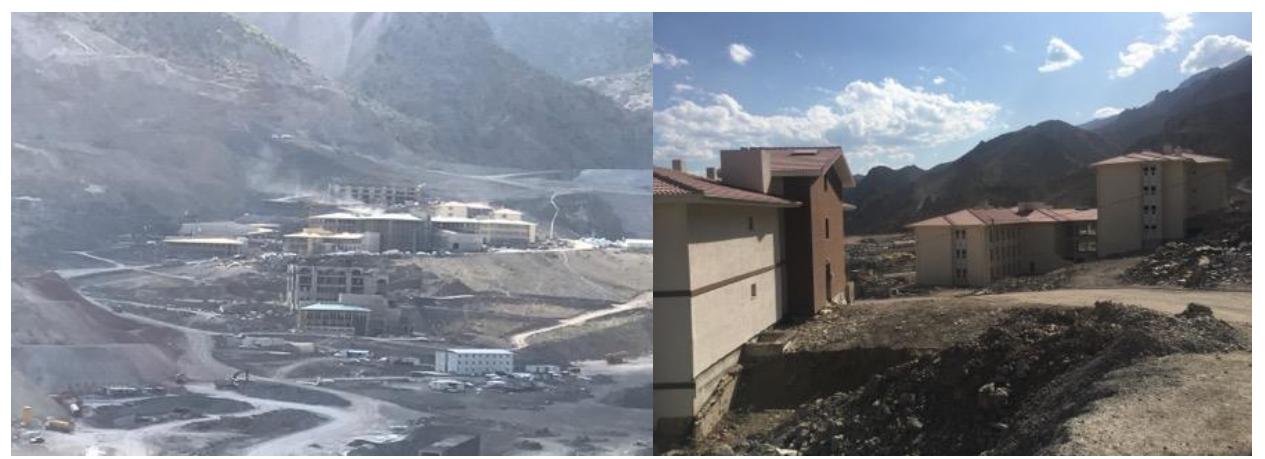

Şekil 12: Yusufeli yeni yerleşim alanından görüntüler

Topoğrafik yapı: Çalışmanın bu kısmında eski ve yeni yerleşim alanları; eğim, yükseklik ve bakı yönünden incelenmiştir.

Ĕ̆im: Yusufeli ilçesi eski yerleşim alanı ve yeni yerleşim alanı eğim haritaları sayısallaştırılmıştır. Eski yerleşim alanı Çoruh Nehri kıyısında dar bir alanda konumlandırılmıştır (Şekil 13a). Yeni yerleşim alanı baraj gölü yanında konumlandırılmıştır. Şekil 13b'de yeni yerleşim alanına ait sayısallaştırılmış olan eğim haritası verilmiştir. 

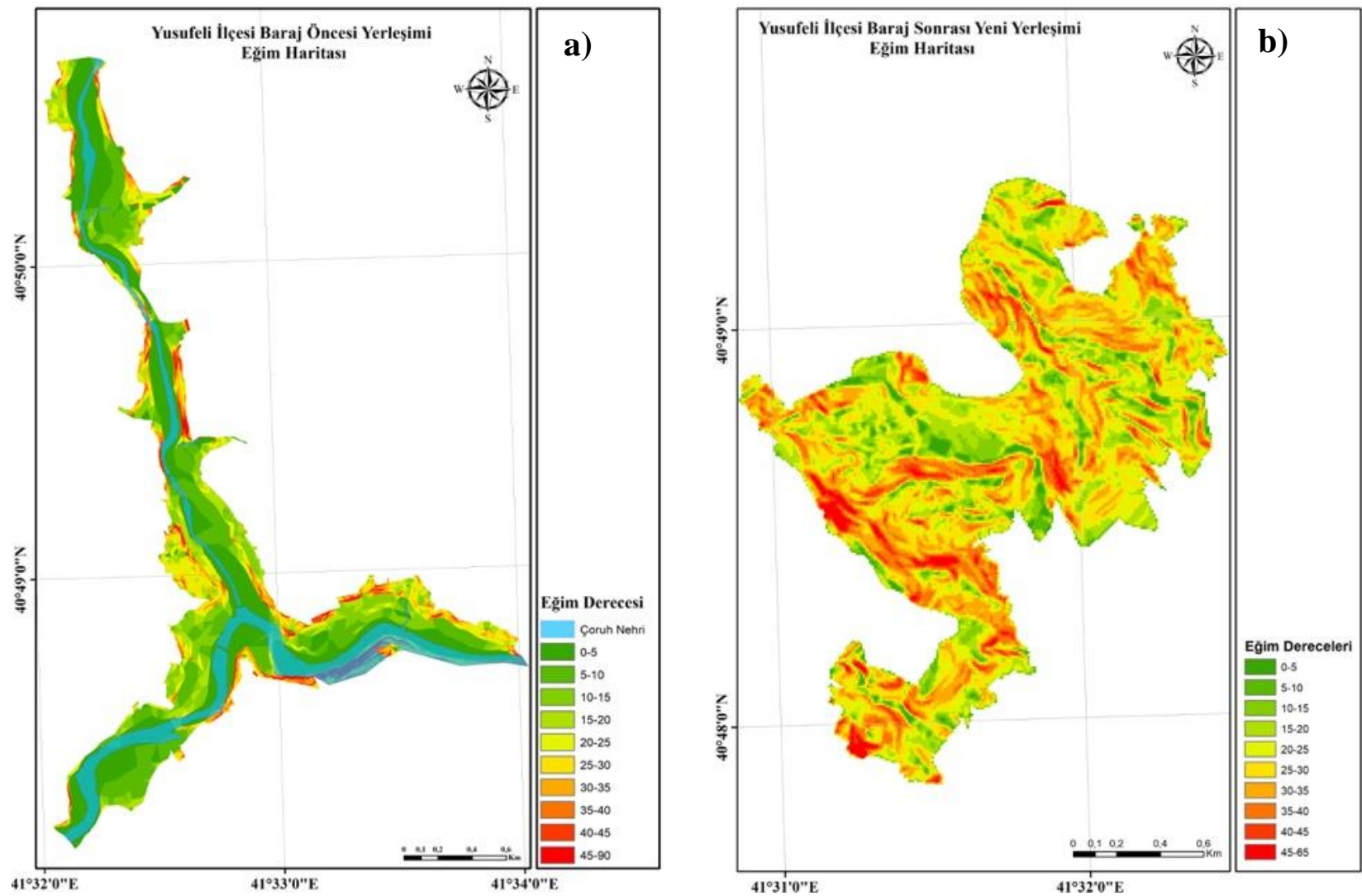

Şekil 13: a) Yusufeli ilçe merkezi eski yerleşim alanına ait eğim haritası, b) Yusufeli İlçe merkezi yeni yerleşim alanına ait eğim haritası

Eğim parametresinin eski ve yeni yerleşim alanı açısından karşılaştırılmasına ait veriler Tablo 2'de verilmiştir. Eski yerleşim alanında $0-5^{\circ}$ eğim değerine sahip alanların oran $\% 40$ iken, 5-10 eğim değerine sahip alanların oranı \%16, 15$20^{\circ}$ eğim değerine ait alanların oranı ise $\% 8$ olmuştur. Yeni yerleşim alanında ise $0-5^{\circ}$ eğim değerine sahip alanların oranı $\% 5,5-10^{\circ}$ eğim değerine ait alanların oran $\%$ 0.96, 15-20 eğim değerine sahip alanların oranı ise \%12.46 olmuştur. Eski yerleşim alanında $0-15^{\circ}$ eğim derecesine sahip alanların toplam alana oranı \%66 iken, yeni yerleşim alanında bu oran \%10'dur. Diğer bir ifadeyle yeni yerleşim yerindeki düz ve düze yakın alanlar oldukça az bir alan kaplamaktadır. Bu nedenle yeni yerleşim yerindeki alanların \%90’ında alan kullanımları için ek tedbirler alınmalıdır. Nitekim çalışma alanında yapılan gözlemlerde 30m'yi aşan istinat duvarlarının yapıldığı tespit edilmiştir. Yeni yerleşim alanının eğim derecelerinin çok dik olmasından dolayı alanda ciddi oranda kazı/dolgu çalışmaları yapılmak zorunda kalınmıştır (Şekil 14).

Tablo 2: Yusufeli ilçe merkezi baraj öncesi ve sonrası eğim derecesi

\begin{tabular}{|c|c|c|c|c|}
\hline Ĕ̆im ( ${ }^{\mathbf{}}$ ) & Eski yerleşim (ha) & Toplam alana oranı & Yeni yerleşim (ha) & Toplam alana oranı \\
\hline $\mathbf{0 - 5}$ & 88,3 & 40,18 & 12,7 & 5,20 \\
\hline $\mathbf{5 - 1 0}$ & 37,3 & 16,97 & 2,3 & 0,96 \\
\hline $\mathbf{1 0 - 1 5}$ & 23,6 & 10,74 & 12,4 & 5,09 \\
\hline $\mathbf{1 5 - 2 0}$ & 18,2 & 8,27 & 30,4 & 12,46 \\
\hline $\mathbf{2 0 - 2 5}$ & 15,1 & 6,85 & 47,4 & 19,40 \\
\hline $\mathbf{2 5 - 3 0}$ & 12,9 & 5,86 & 49,7 & 20,34 \\
\hline $\mathbf{3 0 - 3 5}$ & 10,1 & 4,62 & 40,7 & 16,68 \\
\hline $\mathbf{3 5 - 4 0}$ & 6,5 & 2,98 & 25,2 & 10,33 \\
\hline $\mathbf{4 0 - 4 5}$ & 3,9 & 1,75 & 12,8 & 5,25 \\
\hline$>\mathbf{4 5}$ & 3,9 & 1,78 & 10,4 & 4,28 \\
\hline Toplam & $\mathbf{2 1 9 . 8}$ & $\mathbf{1 0 0}$ & $\mathbf{2 4 4 , 2}$ & $\mathbf{1 0 0}$ \\
\hline
\end{tabular}



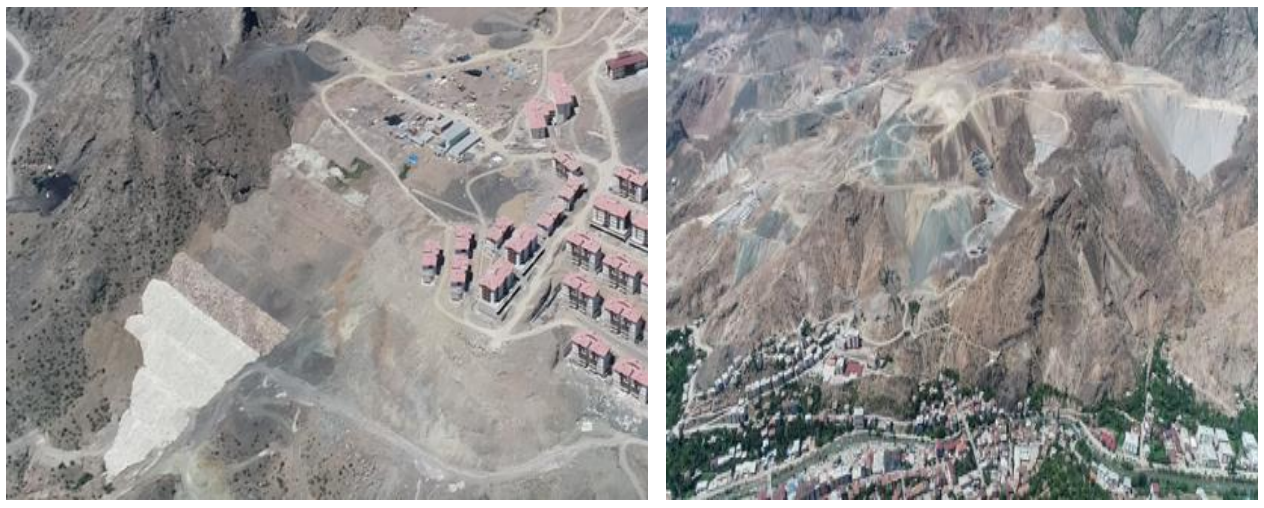

Şekil14: Yeni yerleşim alanında yapılan istinat duvarlarından ve yapılan kazı dolgu çalışmalarından örnekler (Foto: Artvin DSi 26. Bölge Müdürlüğü)

Yeni yerleşim alanı için yapılmış olan jeoteknik etüt raporuna göre; yeni yerleşim alanının 81 ha alanın yerleşime uygun olduğu bunun yanında 273 ha'lık alanın ise yerleşime uygun olmadığı ifade edilmiştir Yine alana ait jeoteknik etüd raporunda da alana ait uygunluk haritası oluşturulmuştur ve yerleşim alanları için önlem alınması gerektiği belirtilmiştir (Encon 2006a, Encon 2006b).

Yükseklik: Eski Yusufeli ilçe merkezi yaklaşık $560 \mathrm{~m}$ yükseklikten $750 \mathrm{~m}$ yüksekliğe kadar çıkmaktadır. Yeni yerleşim yeri su tuttuktan sonra suya kıyı olacak şekilde konumlandırılmıştır. Su kotu 715 m’ye kadar çıkacaktır (Şekil $15)$.

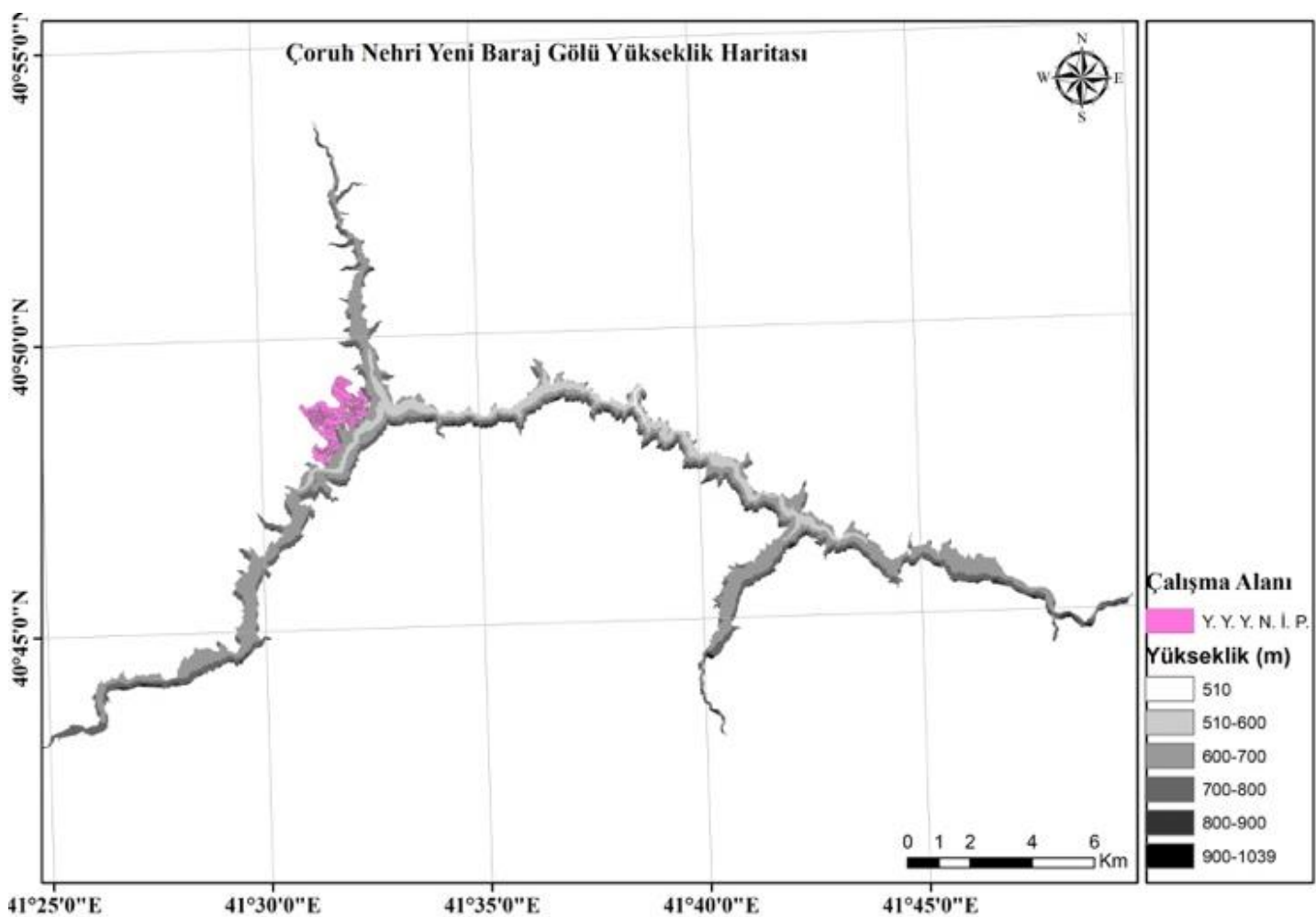

Şekil 15: Yeni oluşacak baraj gölü yükseklik haritası

Yerleşim kotu ise olası taşkınlardan korunma amacı ile güvenli seviye olarak $720 \mathrm{~m}$ olacak şekilde planlanmıştır. İmar planında Yeni yerleşim alanı yüksekliği 950 m’ye kadar çıkmaktadır. Eski ve yeni ilçe merkezi bakı durumu Şekil 16'da verilmiştir. 

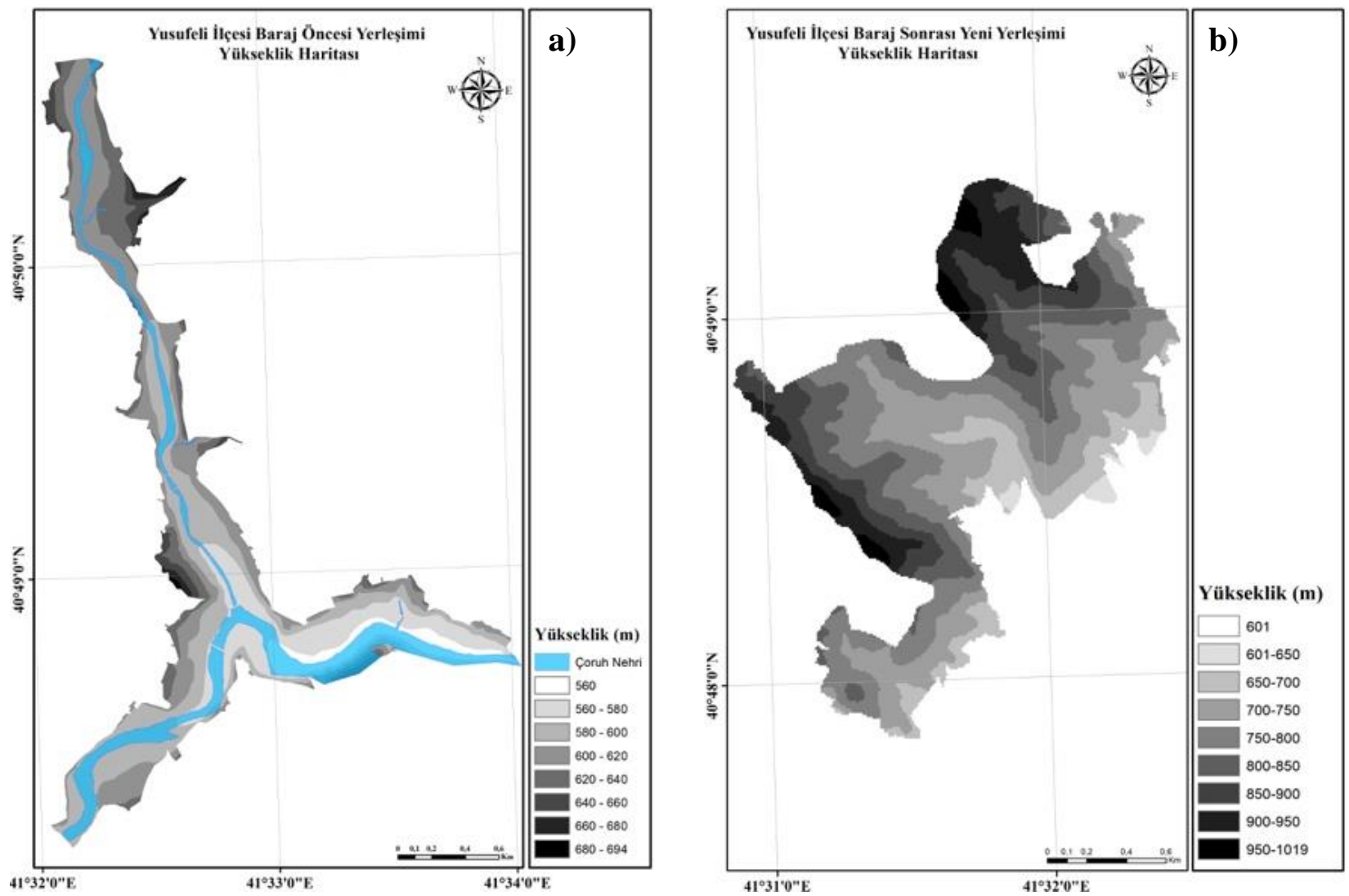

Şekil 16: a) Yusufeli ilçe merkezi eski yerleşim alanına ait yükseklik haritası, b) Yusufeli ilçe merkezi yeni yerleşim alanına ait yükseklik haritası

Yeni yerleşim alanı bakı durumuna ait sayısal veriler Tablo 3'de verilmiştir. Alan güneşli bakı ve gölgeli bakı açısından incelendiğinde; eski yerleşim alanının \%38'inin güneşli bakı \%35'inin ise düz alan olduğu, yeni yerleşim alanının ise \%63'ünün güneşli bakı \%4,5'inin düz alan olduğu görülmektedir. Eski yerleşim alanı Çoruh Nehri'nin iki yanına konumlandırılmıştır. Derin vadi yapısından dolayı adeta sera özelliği taşımaktadır. Yeni yerleşim alanı bakı yönünden daha avantajlı görülmektedir. Yeni yerleşim alanı su kıyısında adeta bir amfi şeklinde alana oturtulmuştur. Yeni yerleşim alanında düz alanı neredeyse hiç yoktur (Şekil 17a, b). Yeryüzü şekilleri kentsel planlama ve peyzaj mimarlığı için önemlidir çünkü kentsel konfor onlara bağlıdır (Yılmaz vd. 2013).

Tablo 3: Yusufeli ilçesi bakı durumu

\begin{tabular}{|c|c|c|c|}
\hline & Yönler & Eski yerleşim (ha) & Yeni Yerleşim (ha) \\
\hline \multirow{4}{*}{ Güneşli Bakı } & Güney & 19.9 & 42.4 \\
\cline { 2 - 4 } & Güneydoğu & 20.2 & 47 \\
\cline { 2 - 4 } & Güneybatı & 22.7 & 20.9 \\
\cline { 2 - 4 } & Doğu & 21.9 & 46.1 \\
\hline \multirow{3}{*}{ TOPLÄlgeli Bakı } & & $\mathbf{8 4 , 7}$ & $\mathbf{1 5 6 . 4}$ \\
\cline { 2 - 4 } & Kuzey & 10.1 & 46.9 \\
\cline { 2 - 4 } & Kuzeydoğu & 15,7 & 2.2 \\
\cline { 2 - 4 } & Kuzeybatı & 14,4 & 6.8 \\
\hline TOPLAM & Batı & 16.8 & $\mathbf{7 6 . 6}$ \\
\hline & & $\mathbf{5 7}$ & 11.2 \\
\hline
\end{tabular}



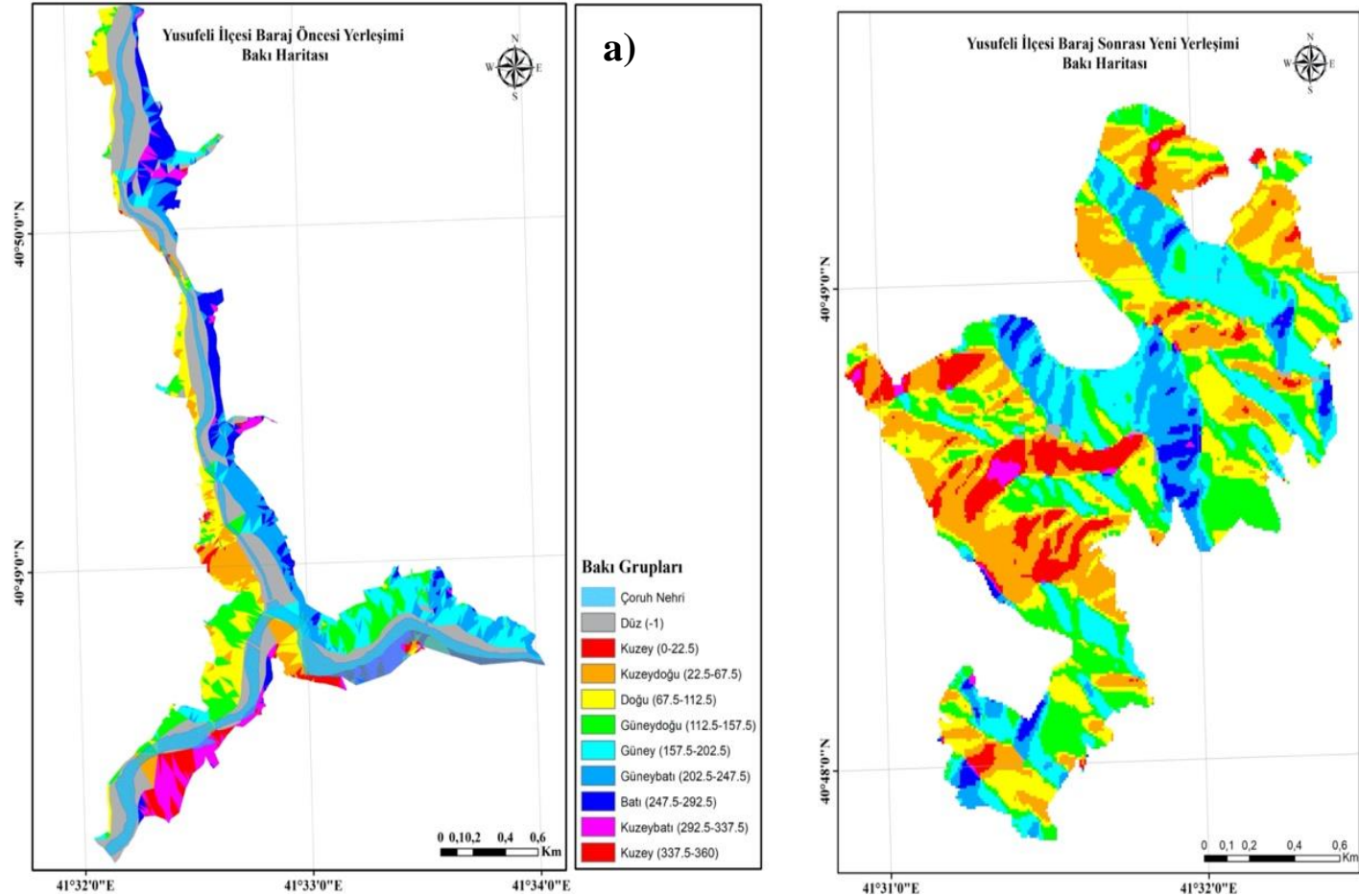

b)

Şekil 17: a) Yusufeli ilçe merkezi eski yerleşim yeri bakı haritası, b) Yusufeli ilçe merkezi yeni yerleşim yeri bakı haritası

Açık yeşil alanlar: Açık yeşil alanlar bina ölçeğinden başlayarak en büyük ölçeğe kadar bir sistem oluştururlar. Farklı bakış açıları ile değerlendirilmiş olsalar da erişilebilirlik ve kişi başına düşen yeşil alan miktarları sınıflandırma açısından önemlidir. Farklı yerleşim ölçeklerinde farklı sınıflandırmalar yapılabilmektedir. Öztürk (2004)'ün yaptığı çalışmada ilçe ölçeğinde açık yeşil alanlar sınıflandırması; orman, su yüzeyi, tarım alanı, çayır-mera, piknik alanı, spor alanı, park yolu, koruluk, trafik yeşilliği, meydan, bahçe ve mezarlık şeklinde yapılmıştır. Öztürk ve Özdemir (2013), yeşil alanları aktif yeşil alanlar ve pasif yeşil alanlar olmak üzere sınıflandırmıştır. Park, çocuk oyun alanı ve spor alanları aktif yeşil alan olarak değerlendirilirken kavşak, refüj, ağaçlandırılacak alan, mezarlık, eğitim, sağlık, askeri vb. kurum bahçeleri, dini tesisler, rekreasyon alanlar vb. alanları pasif alanlar olarak ayırmıştır. Bu sınıflandırma dikkate alınarak Yusufeli ilçesi yeşil alanları incelenmiştir.

Yusufeli eski yerleşim alanında bulunan toplam aktif yeşil alan miktarı yaklaşık 11,4 ha kadardır. Pasif yeşil alan miktarı ise yaklaşık 67,17 ha kadardır. Yusufeli eski yerleşim alanında 2 ha' lık alan spor aktiviteleri için kullanılmaktadır. İlçede ön plana çıkmış olan spor aktivitesi rafting sporudur. Barhal Çayı'nın Yusufeli ilçe merkezine kadar olan kısmı (yaklaşık $75 \mathrm{~km}$ ) önemli parkur alanıdır. Yeni yerleşime ait Nazım İmar Planına göre; ilçe üç bölgeden oluşmaktadır. Yeni yerleşim alanında açık yeşil alan miktarı yaklaşık olarak 9,65 ha kadar iken pasif yeşil alan miktarı 55,1 ha kadardır (Şekil 18a, b). Yeni yerleşim alanında ana bölgede bir adet spor kompleksi, arena ve spor salonu planlanmıştır. Diğer spor alanı ikinci bölgede konumlandırılmıştır. Spor alanı, kapalı spor salonu ve festival alanı olarak görülen alan toplamda yaklaşık $2800 \mathrm{~m}^{2}$ 'lik büyüklüğe sahiptir. Yeni yerleşim alanında planlanan spor alanı büyüklüğü 1,95 ha olarak hesaplanmıştır. Yeni yerleşim alanı için planlanan park alanları ise toplamda yaklaşık 9,3 ha'dır.

Ulaşım: Çalışma alanı ulaşım hattı, Yusufeli Su Kavuşumu-Erzurum karayolu güzergahı ve Yusufeli Su KavuşumuArtvin Deriner Barajı karayolu güzergahı olacak şekilde iki güzergâh olarak incelenmiştir. Süreç içerisinde 31 km ArtvinErzurum güzergahında, $55 \mathrm{~km}$ Artvin-Bayburt güzergahında relokasyon yolları yapılması planlanmışıır. Yapılan baraj ile ulaşım yolları su altında kalacağı için yeni ulaşım hatları oluşturulmuştur. Bu amaçla pek çok tünel ve viyadük bağlantıları kurulmuştur (Şekil 19).

Çalı̧̧ma alanı içerisinde olan, Erzurum- Artvin il sınırından başlayarak Yusufeli ilçesine kadar olan Morkaya, Kınalıçam, Yeniköy, Irmakyanı yolu sular altında kalacaktır. Morkaya’nın Yusufeli'ne olan yeni yol bağlantısı yaklaşı $27 \mathrm{~km}$ uzayacaktır.

Baraj yapım çalışmalarında sırasında yol yapım çalışmalarının büyük bir alanı etkilediği ve değiştirdiği görülmektedir. Yusufeli ilçesi yeni yol yapım çalışmaları ile pek çok tünel, viyadük ve köprü bağlantılarının yapılmaktadır. Yerleşim karakteri yönünden çalışma bölgesi Karadeniz Bölgesi'nin tipik dağınık yerleşimleri görülmektedir. Barajın su tutması ile birlikte su kotundan yukarıda kalan taşınmazlar ve yerleşim alanları değişimden çok fazla etkilenememiştir. Ancak daha düşük kotlarda bu durum oldukça olumsuzluklara yol açmıştır. Örneğin, baraj yapım çalışması aşamasında Sebzeciler Köyü’nde bulunan özellikle yolun altında kalan evlerde; toz ve kaya düşmeleri risklerinin olduğu bu durumun evleri olumsuz etkilediği görülmüştür. 

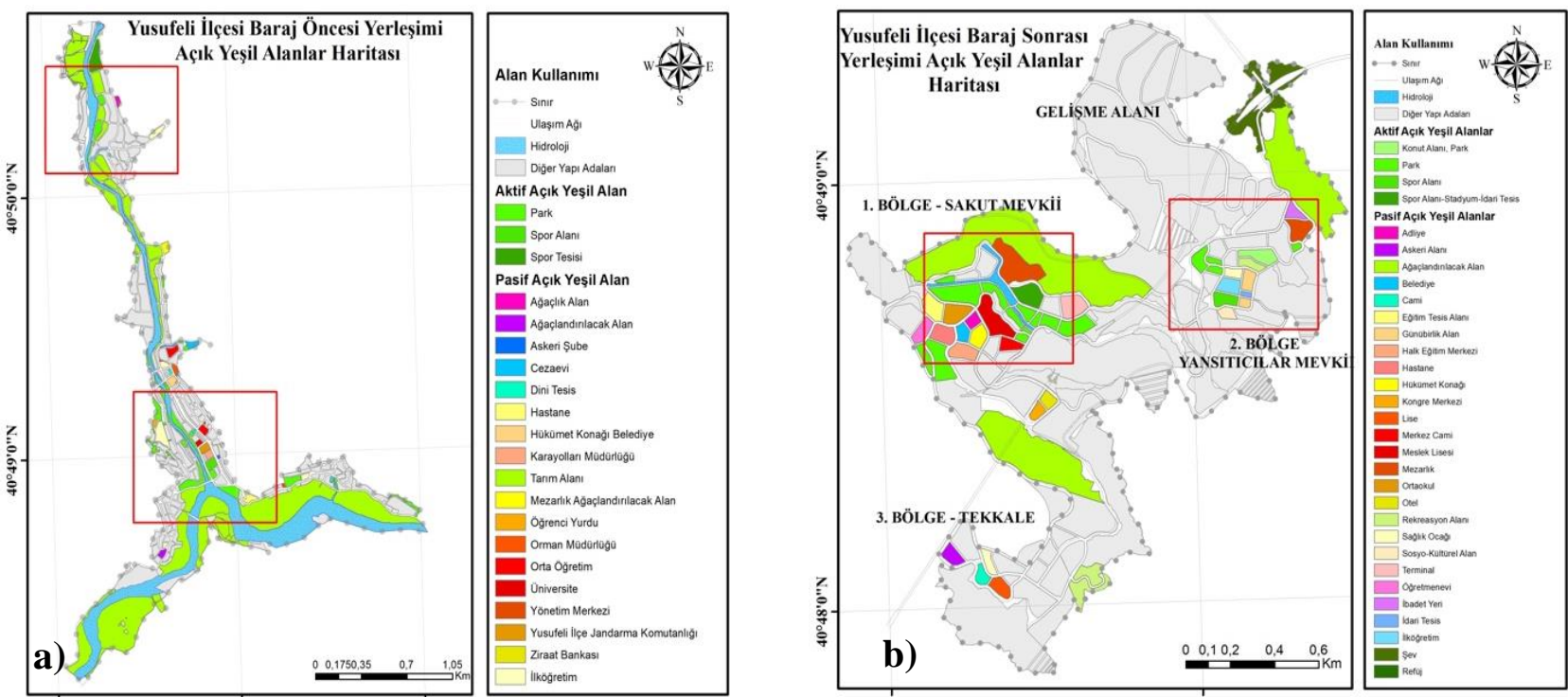

Şekil 18: a) Yusufeli İlçesi mevcut açık yeşil alan durumu, b) Yusufeli İlçesi baraj sonrası açık yeşil alan durumu

Evlerin hemen hemen hepsi ve yetiştiricilik yapılan arazilerin ve zeytin bahçelerinin ise büyük bir kısmı yol yapım çalışmalarından olumsuz etkilenmiştir. Halkın mağdur olmaması için bu alanların kamulaştırılması yol yapım çalışmalarından önce yapılmıştır. Yol yapım çalışmasının bir diğer olumsuz etkisi çalışmalar boyunca yapılan patlatmalardan olmuştur. Özellikle yaban hayatının bu çalışmalardan olumsuz etkilendiği bilinmektedir. Yine yaban hayvanlarının su kaynağına ulaşımı, çiftleşme dönemi gibi aşamalarının yol yapım çalışmalarından dolayı olumsuz etkilendiği bilinmektedir.

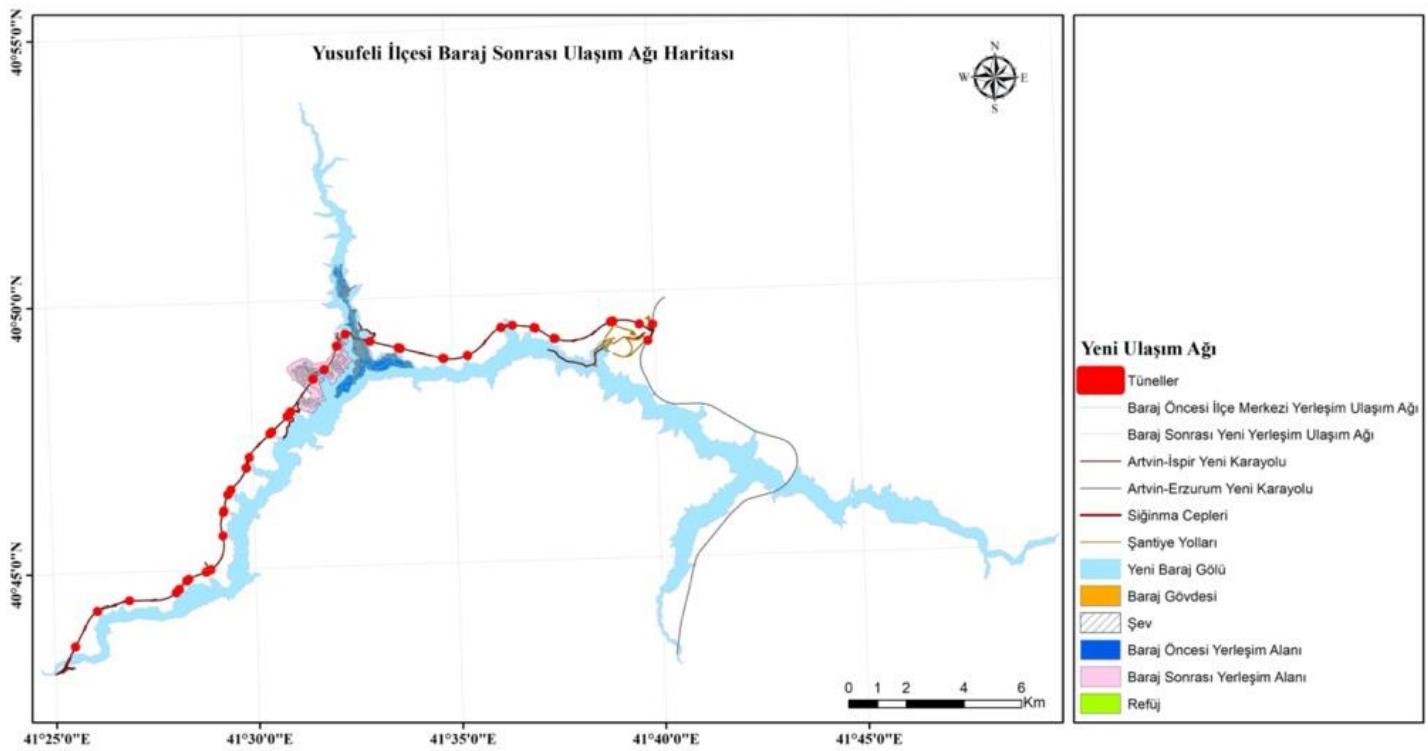

Şekil 19: Yusufeli İlçesi baraj sonrası yeni ulaşım ağı haritası

Orman: Bölgede 1960'dan 1995'e kadar yapılan üretim çalışmaları sonucu; orman dokusu tek tabakalı kompozisyon olarak değişime uğramıştır. Orman dokusu gençtir (Gerçek ve Zeydanlı 2010). Alanın mevcut durumu incelendiğinde ormanlık alanların 700 m rakımdan yukarıda yer aldıkları görülmektedir. Rakımın yüksek olduğu kuzey bakılı alanlarda sarıçam ladin ormanları, güney bakırlı alanlarda saf ladin ormanların varlığından söz edilir. Bozuk orman vasfı olan alanlarda iğne yapraklı bitkiler ve Juniperus sp. türleri bulunmaktadır (Demirel 1997). Yusufeli barajının ormanlık alanlara olan etkisi incelendiğinde, ormanların 44600 ha'lık bir alana sahip olduğu ancak bu alanın 612,5 ha'nın su altında kalacağı görülmüştür (Şekil 20). Su altında kalacak alan kullanımları içerisinde orman alanları, her üç bölgede de en yüksek orana sahiptir. Bunu sırasıyla taşı ağaçsız orman toprağı, tarım arazileri ve kayalık taşlık alanlar izlemiştir. 

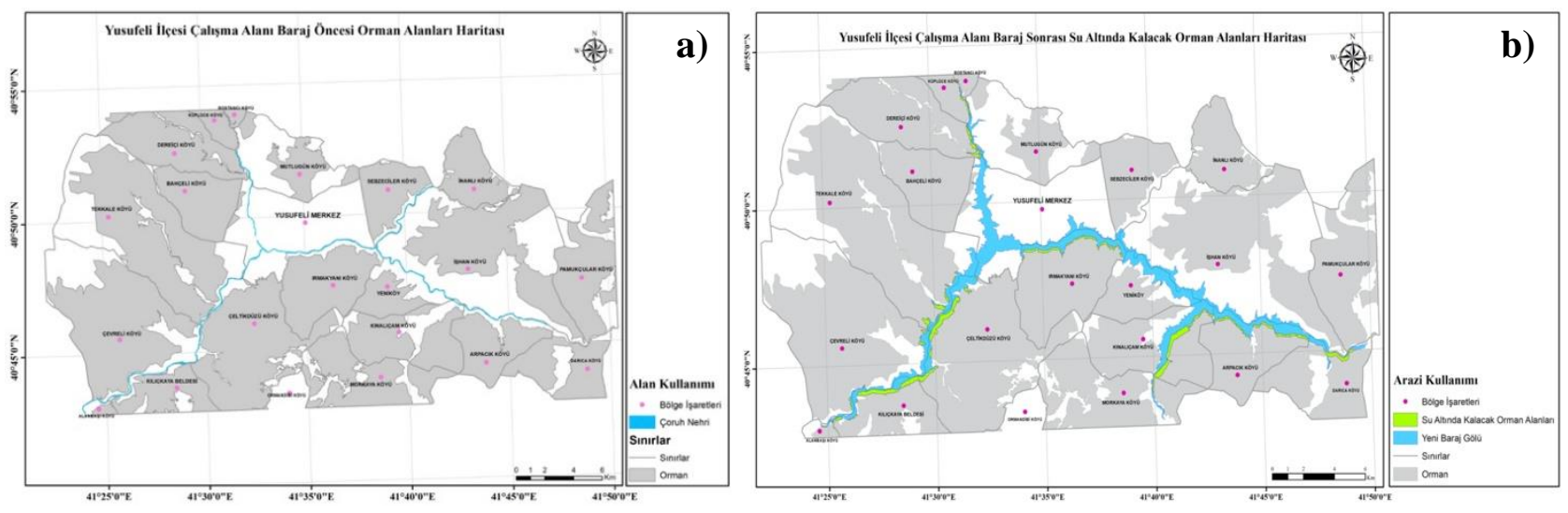

Şekil 20: Yusufeli ilçesi a) baraj öncesi, b) baraj sonrası orman alanları

Korunan Alanlar: Çalışma alanı sınırları içerisinde milletler arası bilinirlik seviyesi "M" olan Yusufeli Kaçkar Dağları Yaban Hayatı Geliştirme Sahası yer almaktadır. Yaklaşık 23222 ha'lık alana sahip olan geliştirme sahası sınırları içinde Yaylalar, Demirdöven, Altıparmak, Bıçakçılar, Özgüven, Yüksekoba, Serinsu, Balaban ve Balcı köyleri yer almaktadır. Alanın denizden yüksekliği yaklaşık 2100 m'dir. Artvin Orman Bölge Müdürlüğü verilerine göre geliştirme sahasındaki hedef tür yaban keçisidir. Alan, 16.10.2005 yılında tescil edilmiş ve geliştirme planı 31.05 .2011 tarihinde revize edilmiştir (URL-2 2020). Alanın karakter türü çengel boynuzlu dağ keçisi ve yaban keçisidir. Bunun dışında alan içerisinde pek çok memeli ve sürüngenler bulunmaktadır. Ayrıca vadi kuş göç yolu üzerinde olmasından dolayı kuşlar açısından da çeşitlilik göstermektedir. Yusufeli barajının su tutması, yaban hayatı geliştirme sahasının bir kısmını da etkileyecektir. Şekil 21 'de yaban hayatı geliştirme sahasının Yusufeli barajının su tutmasından önceki ve sonraki durumu görülmektedir. Çalışma sahası içerisindeki 1.85 ha'lık Çoruh Vadisi Yaban Hayatı Gelişim Sahası (ÇVYHGS)'nın yaklaşık 0.14 ha'ı su altında kalacaktır.
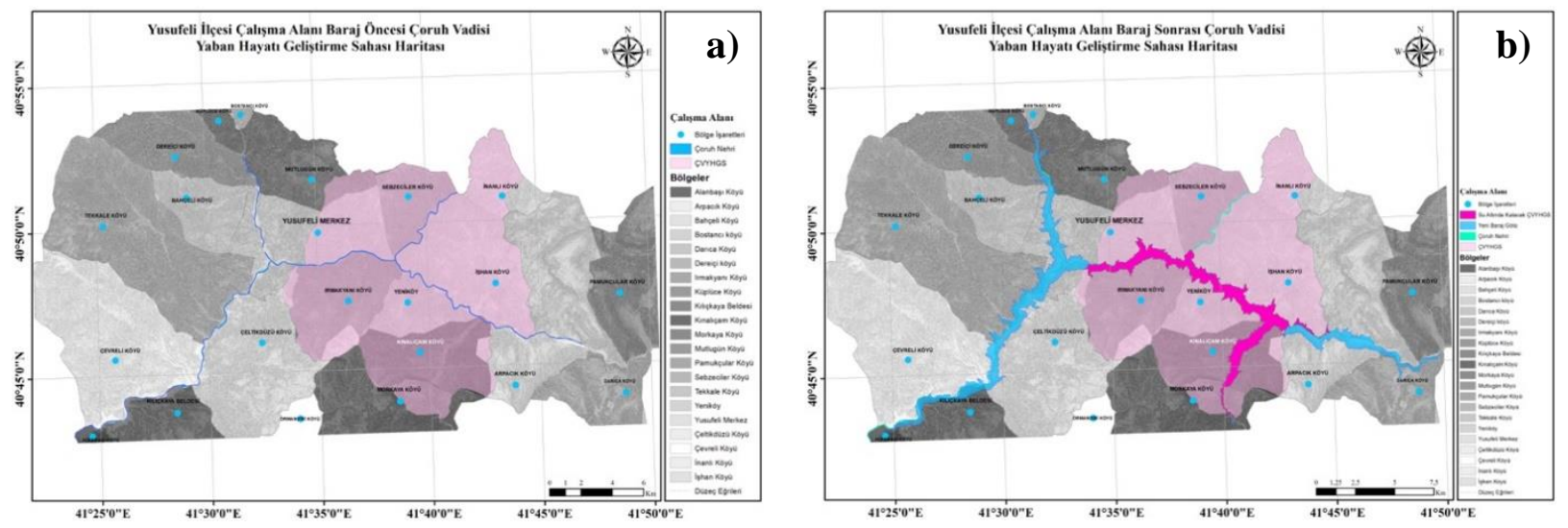

Şekil 21: Yaban hayatı geliştirme sahasının Yusufeli Barajı'nın su tutmasından a) önceki ve b) sonraki durumu

Kopar ve Çakır (2013)'a göre alan jeolojik yönden oldukça çeşitlilik göstermektedir. Çalışma alanı içerisinde korunma statüsü bulunmayan ancak kaynak değeri açısından önemli olan jeolojik oluşumlar bulunmaktadır. Bu dikkat çekici oluşumlar Tortum Gölünün 3 km kuzeyinden başlayarak Kınalıçam köyüne kadar olan 7 km'lik kısım boyunca devam ederler. Doğal ortam henüz bozulmamıştır. Ulaşım yönünden oldukça kolay bir şekilde ziyaret edilebilecek alan oldukça dikkat çekmektedir. Yapılan arazi çalışmalarında da bu çeşitlilik fotoğraflarla belgelenmiştir (Şekil 22).

Kopar ve Çakır (2013)'e göre; çalışma alanımızı da içerisinde bulunduğu Torum Şelalesi ve çevresinde; jeoçeşitlilik derecesine esas teşkil eden jeolojik, jeomorfolojik, hidrografik ve edafik 74 temel unsur tespit edilmiştir. Diğer bileşenlerle yapılan değerlendirme ile alanın jeolojik çeşitlilik derecesinin çok yüksek olduğu ifade edilmektedir. Baraj sonrası alan durumu Şekil 23'de verilmiştir.

Çalışma alanında bulunan dikkat çekici jeolojik oluşumlar suyun dolması sonucu farklı bir peyzaj karakteri gösterecektir. Erzurum Artvin yolu güzergâhı üzerinde bulunan Morkaya, Kınalıçam mevkilerinde olan bu alanlarda yol farklı bir güzergâhtan geçecektir. Bu durum eşsiz güzellikte olan bu alan için iyi değerlendirilirse olumlu sonuç olabilir. 

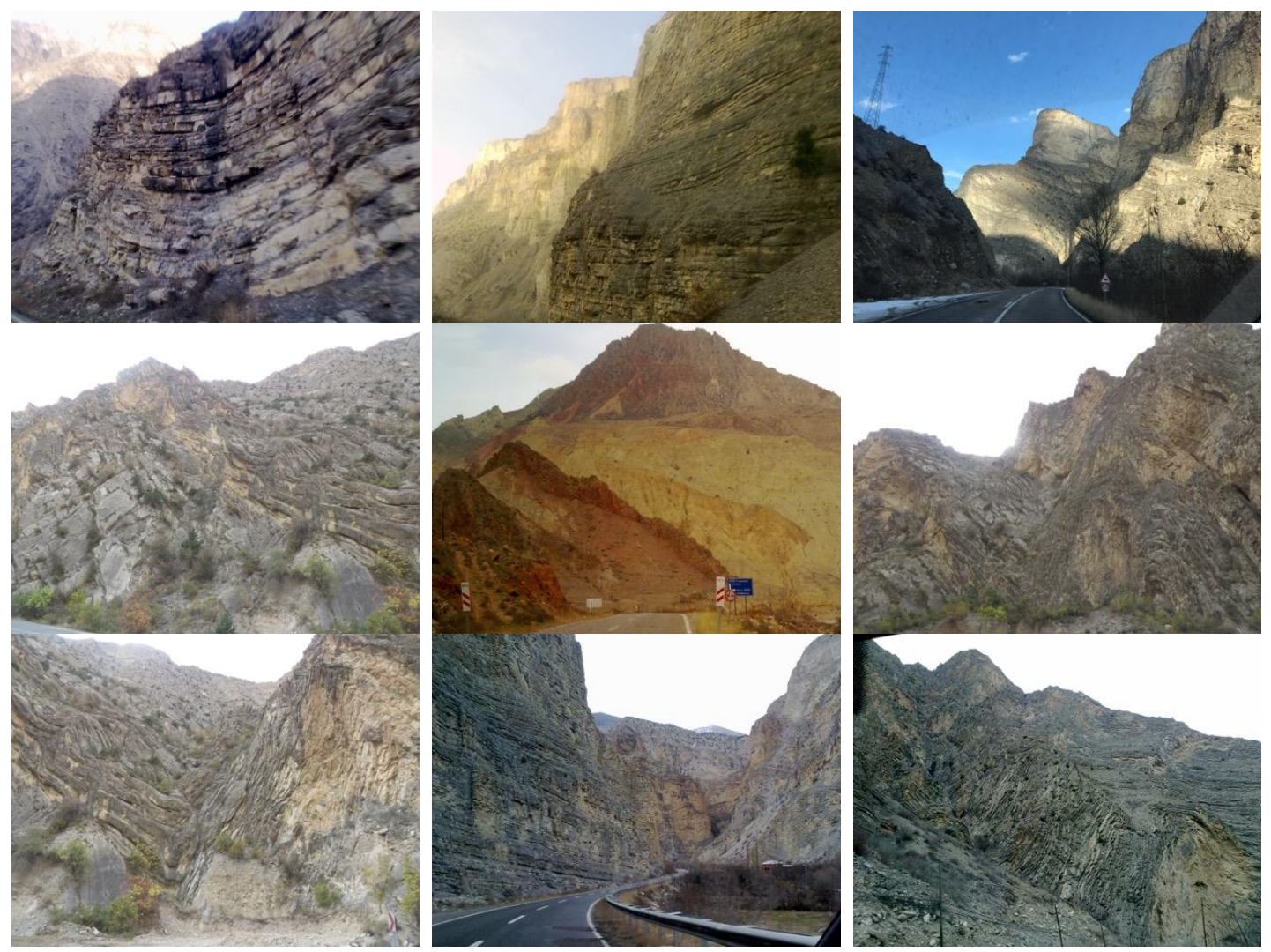

Şekil 22: Çalışma alanındaki dikkat çekici jeolojik oluşumlar koridoru

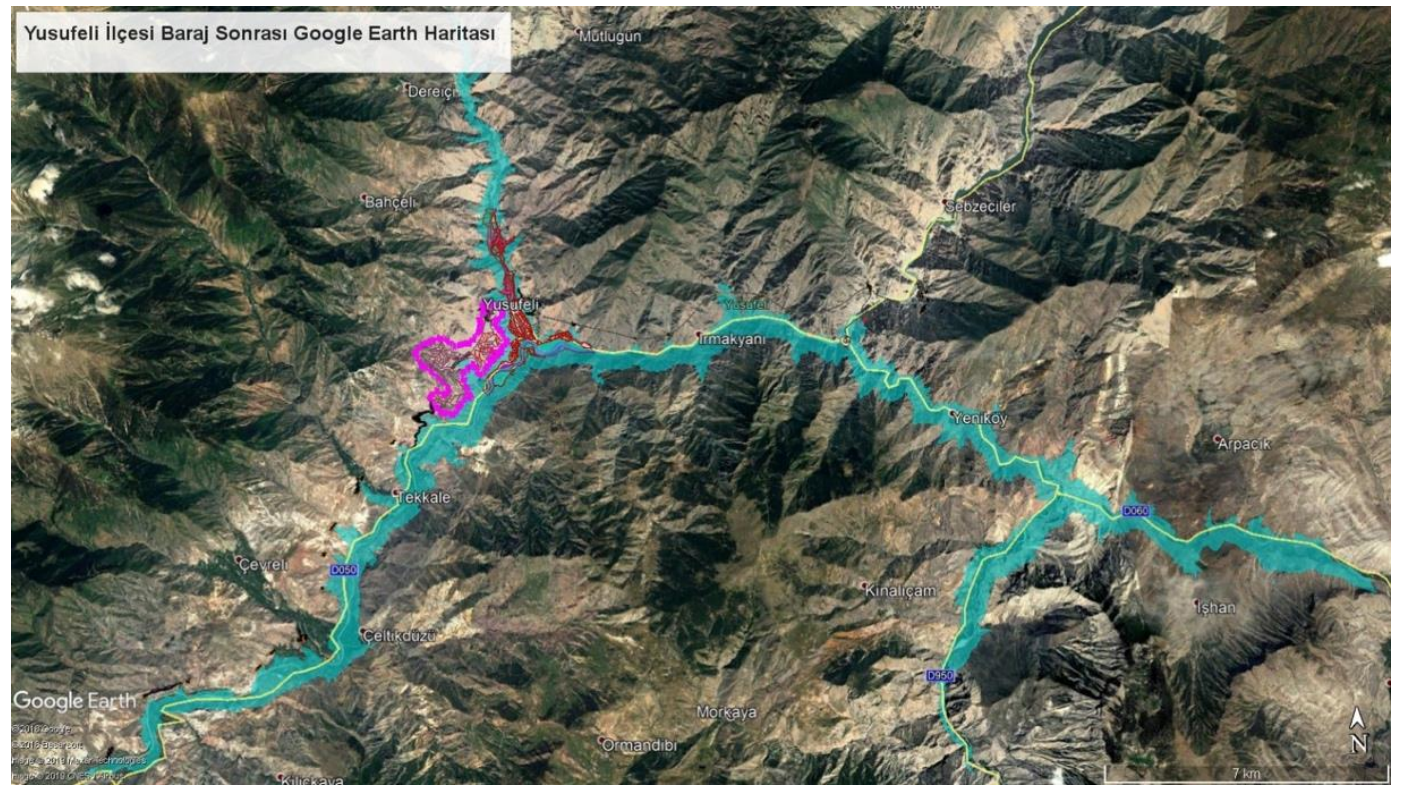

Şekil 23: Baraj sonrası alanın jeolojisinde meydana gelecek değişim

Kültür Varlıkları: Yusufeli ilçesi taşınmaz kültür varlıkları açısından incelendiğinde ilçe merkezinin önemli kaynak değerlerinin olmadığı ancak köylerde özellikle geleneksel mimari dokunun önemli örneklerinin bulunduğu görülmektedir. Su altında kalacak kültür varlıkları; Öğdem Kalesi, Tekkale, Çevreli Kalesi ile Barhal Kilisesi, İşhan Kilisesi ve Dört Kilise Manastırı Yusufeli Baraj ve HES etkilenme alanı içerisindedir. Ancak Tekkale'nin rezervuar alanında kaldığı ve su tutulmaya başlamadan önce yeni bir yere taşınacağı ÇED raporunda ifade edilmektedir (Başkan 2017). 


\section{Sonuç}

Bu çalışma ile Coğrafi Bilgi Sistemleri kullanılarak, Yusufeli Baraj yapımı sonrası antropojenik etkiler sonucu oluşacak alan değişimleri değerlendirilmiştir. Türkiye'nin birinci dünyanın ise üçüncü yüksek barajı olan Yusufeli Barajı, yapımı ve sonrası ile kendine has bir coğrafyanın tamamen değişmesine yol açmıştır. Değişim, gelişimi de beraberinde getirdiği sürece anlamlıdır. Yapılan Yusufeli Barajı ve bunun gibi büyük ölçekli projelerde sürdürülebilirliği sağlamak, antropojen baskıları en aza indirgemek, geleceğe yönelik planlamalara 1şık tutmak en önemli sorumluluktur. Enerji üretimi bölge ihtiyaçlarından daha çok ülke ihtiyaçları göz önüne alınarak planlanmaktadır. Dünya üzerindeki politik gelişmeler ülkemizin kendi enerjisini üretmesini zorunlu kılmaktadır. Küresel ısınma ve kuraklık sorunları da dikkate alınırsa su yönetimi çalışmalarının önemi ve her türlü detayların planlama aşamalarında dikkatlice ele alınması gerekliliği ortaya çıkmaktadır. Yusufeli Barajı örneğinde büyük ölçekli planlamalarda antropojenik etkilerin en aza indirilmesi için bazı öneriler aşağıda sunulmuştur.

Ekolojik değeri yüksek alanların sürdürülebilirliğini sağlamak için bütüncül havza planlamaları yapılmalıdır. Farklı meslek disiplinlerinin, yerel halkın katılımları sağlanmalıdır. Doğacak farklılıklar halka net olarak anlatılmalı, beklentileri anlaşılmalı, refah seviyelerini artırıcı tedbirler alınmalıdır. Geleneksel yaşam tarzına uygun planlamalar yapılmalı kaynak kullanımları için firsatlar oluşturulmalıdır. Kültürel dokunun en az zarar görecek şekilde değişime ayak uydurması sağlanmalıdır. Master planlar hazırlanmalı ve buna uygun yönetim planları oluşturulmalıdır. Yanlış hesaplamalar ile doğacak her türlü zarar için alternatif planlar ve afet yönetim planları, oluşturulmalıdır. Yusufeli ilçesi yeni yerleşim alanının sonraki aşamasında görülen en büyük sorunlardan birisi altyapı çalışmalarının yapılmamış olmasıdır. Bu tür büyük yatırımlarda alt yapı çalışmaları, öncelikli olarak çözülmelidir. Yeni yerleşim alanlarında optimal alan kullanımları dikkate alınmalıdır. Dik yamaçlarda yapılan arazi çalışmaları için alınması gerekli ek tedbirler önceden hesaplanmalıdır.

Çalışmanın bütününde pek çok plan, rapor incelenmiş ve uzman kişiler de dahil olmak üzere pek çok kurumla bağlantı kurulmuştur. Ancak yapılan planlamalarda peyzaj mimarlarının olmadı̆̆ı ve alandaki değişimler için peyzaj planlamalarının yapılmadığı görülmüştür. Bunun sonucu olarak yapılan çalışmalar hep tek taraflı ele alınmış bütüncül bakış açısı sergilenememiştir. Bu durumun ortaya çıkardığı olumsuzlukların en önemlisi kültürel peyzajın yok sayılması, sadece planlamanın fiziksel aşamada yürütülmeye çalışılmasıdır. Kültürel peyzajın yok olmaması için yerel ölçeklerde koruma ve planlama kararları alınmalıdır. Yaban yaşamının proje aşamalarında ve sonrasında oluşacak değişimlerden olumsuz etkilenmemesi için alana özgü ekolojik planların yapılması gerekmektedir. Yaşam alanlarının daralmaması için ekolojik köprüler oluşturulmalıdır. Hayvanların çiftleşme zamanları ve üreme zamanları için ek tedbirler alınmalıdır. Halkın en çok üzerinde durduğu konu yaşam alanları ve refah bir gelir seviyesidir. Refah seviyesinin artırılmasında turizm alternatif bir çözümdür. Yeni yerleşim alanında turizm açısından yapılabilecek çalışmalar dikkate alınmamıştır. Kıyı faaliyetleri ve turizm faaliyetleri için firsatlar oluşturulmalıdır.

Çalışma alanının toprak yapısı da dikkate alınarak alanda tarımsal üretim için ek tedbirlerin alınması gerekmektedir. Baraj sonrası yeni tarım alanlarının açılabilmesi ve tarımsal üretim yapılabilmesi için ıslah çalışmaları yapılarak arazinin verimli hale getirilmesi gerekmektedir. Yeni yerleşimde yetiştiricilik için emek ve zamana ihtiyaç olacaktır. YusufeliMorkaya bölgesinde görülen jeolojik oluşumlar gibi kaynak değeri yüksek alanlar için koruma statüsü getirilmelidir. Alana ulaşım karayolu ile sağlanamayacağı için su yolu kullanılmalı, kayıkla gezinti güzergâhları oluşturularak turizm açısından değerlendirmeler yapılmalıdır. Peyzaj Tasarımı çalışmaları ile alan bölgesel ölçekle cazibe alanı haline dönüştürülebilir.

\section{Teşekkür}

Bu makale, Belgin YILMAM'ın Artvin Çoruh Üniversitesi, Fen Bilimleri Enstitüsü, Peyzaj Mimarlı̆̆ı Anabilim Dalı'nda tamamlanan yüksek lisans tezinden üretilmiştir.

\section{Kaynaklar}

Aksu G., (2015), Barhal Vadisi (Yusufeli) ve yakın çevresinin florası, Yüksek Lisans Tezi, Artvin Çoruh Üniversitesi Fen Bilimleri Enstitüsü, Artvin.

Bağc1 H.R., Bahadır M., (2018), Effects of climate change and anthropogenic pressure on the wetlands of Yeşilırmak Delta (Samsun), The 2nd UNIDOKAP International Symposium on "Biodiversity", 28-30 November, Ondokuzmayis University, Samsun.

Demirel Ö., (1997), Çoruh Havzası (Yusufeli Kesimi) doğal ve kültürel kaynak değerlerinin turizm ve rekreasyon potansiyeli açısından değerlendirilmesi üzerine bir çalışma, Doktora tezi, Karadeniz Teknik Üniversitesi, Fen Bilimleri Enstitüsü, Trabzon.

Eminağaoğlu Ö., Tilki F., (2015), Yusufeli Barajı su aynası altında kalacak alanda bulunan risk altındaki (endemik ve endemik olmayan nadir) bitkiler ve botanik bahçesi, Yusufeli Barajının İlçeye Etkileri’nin İçinde, (Demirel F., Ed.), Yusufeli Belediyesi Yayınları, Samsun, ss. 251-287.

Encon, (2006a), Yusufeli Barajı ve HES yeniden yerleşim eylem planı, Bölüm 6. Yeniden Yerleşim Alanları, DSİ, Ankara.

Encon, (2006b), Yusufeli barajı ve HES projesi çevresel etki değerlendirme raporu, DSİ, Ankara.

Ertek T.A., (2017), Antropojenik jeomorfoloji: konusu, kökeni ve amacl, Türk Coğrafya Dergisi, 69(2017), 69-79.

Gercek D., Zeydanl1 U., (2010), Object-based classification of landscape into land management units (LMUs), Third international Conference on Geographic Object-Based Image Analysis (GEOBIA), 29 June - 2 July, Ghent, Belgium. 
Göktürk T., Bucak F., Artvinli T., (2011), Mammalian fauna of Artvin, African Journal of Agricultural Research, 6(6), 1418-1425.

Gülgün B., Tahta T.B., Esetlili M.T., Aktaş E., (2012), İzmir kent örneğinde bazı kentsel sitlerdeki antropojenik baskıların irdelenmesi üzerinde bir araştırma, Ege Üniversitesi Ziraat Fakültesi Dergisi, 49(2), 187-193.

Gülgün B., Tahta B.T., Esetlili M.T., Turan İ.A., Aktaş E., (2011), İzmir ilinde bazı arkeolojik sit alanlarına antropolojik baskılar üzerine bir çalışma, Selçuk Tarım ve Gıda Bilimleri Dergisi, 25, 72-78.

Goudie A., (2007), The Human Impect of Environment, 6 th Edition, Blackwell, Oxford, 376 ss.

Karabulut K., (2007), Yusufeli kent dokusunun tarihsel gelişimi ve sanat yapıları, Yüksek Lisans Tezi, Yüzüncü Yıl Üniversitesi Sosyal Bilimler Enstitüsü Sanat Tarihi Anabilim Dalı, Van.

Irmak M.A., Y1lmaz S., Dursun H., (2017), Effect of different pavements on human thermal comfort conditions, Atmosfera, 30(4), $355-$ 366.

Irmak M.A., Y1lmaz S., Mutlu E., Y1lmaz H., (2018), Analysis of different urban spaces on thermal comfort in cold regions: A case from Erzurum, 10th International Conference on Urban Climate - 14th Symposium on Urban Environment, 6-10 August, New York.

Irmak M.A., Y1lmaz S., (2019), Analysis of microclimatic thermal comfort between urban transformation areas and urban centers, International Civil Engineering and Architecture Conference, 17-20 April, Trabzon, ss. 1018-1026.

KHGM, (2000), Erzurum ili arazi varlı̆̆ı, T.C. Başbakanlık Köy Hizmetleri Genel Müdürlüğü Yayınları, İl Rapor No: 25, 1-30, Ankara.

Kopar İ., Çakır Ç., (2013), Tortum Gölü-Tortum Boğaz Vadisi ve yakın çevresinin (Uzundere-Erzurum ve Yusufeli-Artvin) serrano ve ruiz-flaño yöntemiyle jeoçeşitlilik derecesinin belirlenmesi, Coğrafya Dergisi, 27, 46-66.

Kurt B., Balkız Ö., (2011), Kaçkar dağları Yusufeli bölgesi yönetim planı 2011, TEMA, Türkiye Erozyonla Mücadele, Ağaçlandırma ve Doğal Varlıkları Koruma Vakfi, Ankara, 128 ss.

Küçük F., Gülle İ., Güçlü S.S., (2018), Antalya Havzası akarsularındaki yılan balığı göçleri üzerine antropojenik baskılar, Mehmet Akif Ersoy Üniversitesi Fen Bilimleri Enstitüsü Dergisi, 9 (Ek Sayı 1), 285-296.

Küçükbaşol Y., (2015), Çoruh Nehri ve Yusufeli Barajı: toplumsal, ekonomik ve çevresel etkileri bakımından bir baraj incelemesi, Birey ve Toplum Sosyal Bilimler Dergisi, 5(10), 133-158.

Muluk C..B., Turak A., Yılmaz D., Zeydanlı U., Bilgin C.C., (2009), Hidroelektrik santral etkileri uzman raporu: Barhal Vadisi, http://sertifika.tema.org.tr/_Ki/CevreKutuphanesi/Documents/HES_Etkileri_Raporu.pdf, [Erişim 15 Mart 2020].

Özşahin E., Eroğlu İ., (2017), Tekirdağ ilinin antropojenik biyomlarinin (antronomlarin) zamansal ve mekânsal değişimi, Marmara Coğrafya Dergisi, 35, 218-227.

Öztürk B., (2004), Kentsel açik ve yeşil alan sistemi oluşturulması: Kayseri kent bütünü örneği, Doktora Tezi, Ankara Üniversitesi Fen Bilimleri Enstitüsü Peyzaj Mimarlığı Anabilim Dalı, Ankara.

Öztürk B., Özdemir Z., (2013), The effects of urban open and green spaces on life quality; a case study of Kastamonu, Kastamonu Üniversitesi Orman Fakültesi Dergisi, 13(1), 109-116.

Sucu S., Dinç T., (2008), Çoruh Havzası projeleri, TMMOB 2. Su Politikaları Kongresi, 20-22 Mart, Ankara, ss.33-38.

Şerifaki E.A., (2006), İzmir Körfezi örneğinde antropojenik etkiler ve sonuçları üzerine araştırmalar, Doktora Tezi, Ege Üniversitesi Fen Bilimleri Enstitüsü, İzmir.

Türk E., Erkan G.H., (2018), Gömleğin her düğmesini yanlış iliklemek: Artvin-Yusufeli zorunlu yeniden yerleştirme sürecinin eleştirel incelemesi, Planlama Dergisi, 28(2), 218-235.

Uçarlı, Y., (2016). Çoruh Vadisi ve Verçenik Dağı Yaban Hayatı Geliştirme Sahalarındaki Barajların Yaban Keçisi Üzerine Etkileri, Doktora Tezi, Artvin Coruh Üniversitesi, Fen Bilimleri Enstitüsü, Artvin.

URL-1, (2020), Iklim Yusufeli, https://tr.climate-data.org/asya/tuerkiye/artvin/yusufeli-19361/2 [Erişim 15 Nisan 2020].

URL-2, (2020), Yaban Hayatı Geliștirme Sahalarl, https://www.tarimorman.gov.tr/DKMP/Belgeler/Korunan\%20Alanlar\%20Listesi/ 6-YABAN\%20HAYATI\%20 GELIŞTIRME\%20SAHALARI.pdf, [Erişim 15 Nisan 2020]

Walker H.J., (1991), Antropojenic landforms in the coastal zone, Jeomorfoloji Dergisi, Özel Say1, 19, 1-12.

Yavuz Özalp A., Akıncı H., Temuçin S., (2013), Artvin ili arazisinin topografik ve bazı fiziksel özelliklerinin tespiti ve bu özelliklerin arazi örtüsü ile ilişkisinin incelenmesi, Artvin Çoruh Üniversitesi Orman Fakültesi Dergisi, 14(2), 292-309.

Yetilmezsoy K., (2006), Uçaklardan kaynaklanan emisyonların çevresel etkileri, UTED Aylık Havacılık Dergisi, 171(2), 33-35.

Y1lmaz S., Irmak M.A., Matzarakıs A., (2013), The importance of thermal comfort in different elevation for city planning, Global NEST Journal, 15(3), 408-420. 